Article

\title{
Das alte Frankfurt: Urban Neighborhood versus Housing Estate, the Rebirth of Urban Architecture
}

\author{
Silvia Malcovati ${ }^{1,2}$ \\ ${ }^{1}$ Department of Architecture and Design, Politecnico di Torino, 10125 Torino, Italy; E-Mail: silvia.malcovati@polito.it \\ 2 School of Architecture, Potsdam University of Applied Sciences, 14469 Potsdam, Germany; \\ E-Mail: malcovati@fh-potsdam.de
}

Submitted: 31 March 2019 | Accepted: 21 June 2019 | Published: 30 September 2019

\begin{abstract}
On the eve of the celebration of the 90th anniversary of 1929's CIAM, the city of Frankfurt is again the center of international attention thanks to a project related to housing and the city, which represents, however, the opposite of the experience of Das neue Frankfurt. I refer to the Dom-Römer, the heart of the historical city, destroyed by bombing during WWII, replaced in the post-war period by the Technisches Rathaus, and now "rebuilt" in total adherence to the historical parcel plan as a new residential and commercial district. Regarding mass public housing, with minimal individual dwelling cells and standardized construction conceived by Ernst May, an equally public intervention is now opposed, but with a few individual houses and owned apartments for upper-middle-class customers, unique in their exceptionality, constructed with traditional techniques and finished with craftsmanship, case by case. The modernistic idea of low-density monofunctional satellite neighborhoods on the edge of the consolidated city, based on repetition of typed elements and on correct orientation of buildings in order to grant air and light, at the expenses of a clear definition of public space, is replaced today, in the core the city, by the medieval plan, with its irregular parcels and the narrow, winding dark alleys, high density and multifunctional buildings, and a strongly characterized public space. The positions are of course diametrically opposed also with respect to the roof dispute, which animated architects at the beginning of the 20th century: strictly flat roofs in the new Frankfurt of the 1920s and pitched roofs in the gabled houses of the ancient contemporary Frankfurt. From the parallel between these two experiences, so different from one another that they are almost incomparable, important elements emerge to understand the current debate on the architecture of the European city, particularly in Germany.
\end{abstract}

\section{Keywords}

architectural typology; European city; Frankfurt; German architecture; housing estate; housing in the city; urban design; urban morphology; urban neighborhood

\section{Issue}

This article is part of the issue "Housing Builds Cities", edited by Luca Ortelli (École Polytechnique Fédérale de Lausanne, Switzerland), Chiara Monterumisi (École Polytechnique Fédérale de Lausanne, Switzerland), and Alessandro Porotto (École Polytechnique Fédérale de Lausanne, Switzerland).

(C) 2019 by the author; licensee Cogitatio (Lisbon, Portugal). This article is licensed under a Creative Commons Attribution 4.0 International License (CC BY).

\section{Introduction}

The coincidence of the 90th anniversary of the Frankfurt CIAM (Congrès Internationaux d'Architecture Moderne) in 1929, dedicated to Die Wohnung für das Existenzminimum, and to the concrete experience of Das neue Frankfurt, with the inauguration of the new ancient city center in the Dom-Römer area-just awarded as the
MIPIM Best Urban Regeneration Project-offers an interesting starting point for a reflection on the current state of the discussion on architecture and the European city, particularly in Germany. These two experiments, in fact, embody the two extreme positions that characterized the debate on the role of housing in urban design from the start, at the end of the nineteenth century, and which are today again at the center of the discussion: 
they identify the opposition between Siedlungsbau and Städtebau, between Trabantenstadt and Stadtquartier (settlement construction and urban development, satellite town, and urban neighborhood) which is still the crucial problem of architecture when confronted with growing cities.

\section{Research Question}

The purpose of this article is to reflect on the current state of urban design, especially in Germany, by following the common thread of urban architecture (Stadtarchitektur). To consider urbanity as a methodological tool for the design of the contemporary city means to question most of the current positions dominated by the globalization of architectural languages, in which building technology and sustainability are exhibited as an aesthetic value, and to focus conversely on the spatial values of urban architecture and the production mechanisms of the public space in the city. This is primarily a cultural issue, but it is also a political and economic issue, which directly affects the principles and forms of construction of the European city over time.

This common thread, which characterizes the history of European architecture as an urban phenomenon, gradually dissolves at the beginning of the 20th century with the advent of modern urbanism, then it disappears drastically in the second post-war period and emerges again, in theory, starting from the Sixties and comes back to the center of attention today, in practice, thanks to some projects proposing urbanity as a spatial and cultural value, essential for the future of the European city.

Until the WWII, Siedlungsbau and Städtebau, Gartenstadt and Großstadt (settlement construction and urban development, garden city, and big city) coexisted as two possible alternatives to the uncontrolled and speculative development of growing cities. Although the historiography of international modernism, from Giedion onwards, tended to give a unilateral reading of early twentieth century architectural history, centered on the individuality of the "Masters" and their architectural work conceived as an object propagating the dissolution of the city into the landscape (Giedion, 1941; Scalvini \& Sandri, 1984), it has been definitively demonstrated that it is a partial interpretation. The most recent studies have shown that the urban proposals for collective living which deal with urbanity and density, with the urban block and the neighborhood as a medium-scale multifunctional unit, are equally numerous and significant, especially in the field of mass housing (Bullock \& Read, 1985; Rodriguez-Lores \& Fehl, 1988; Sonne, 2009, 2014, 2016).

Urban projects by Alfred Messel, Albert Gessner, Paul Mebes or Paul Jatzow for urban residential ensembles in Berlin play a prominent role in the German panorama anticipating the vision of the 1910 Gro $\beta$ Berlin competition (Gessner, 1909; Posener, 1979, pp. 240-263, 319-368; Sonne, 2009). This competition represents a milestone in the discussion on urban architecture. The cultural climate in which it was conceived was marked by an international urban discourse, a science-based, multidisciplinary, theoretical approach, and cross-scale design practice. Thanks to this complex cultural and disciplinary situation, a comprehensive, integral urban planning method emerges, with the aim of concretely prefiguring the modern metropolis up to the architectural scale (Tubbesing, 2018; see Figures 1, 2 and 3).

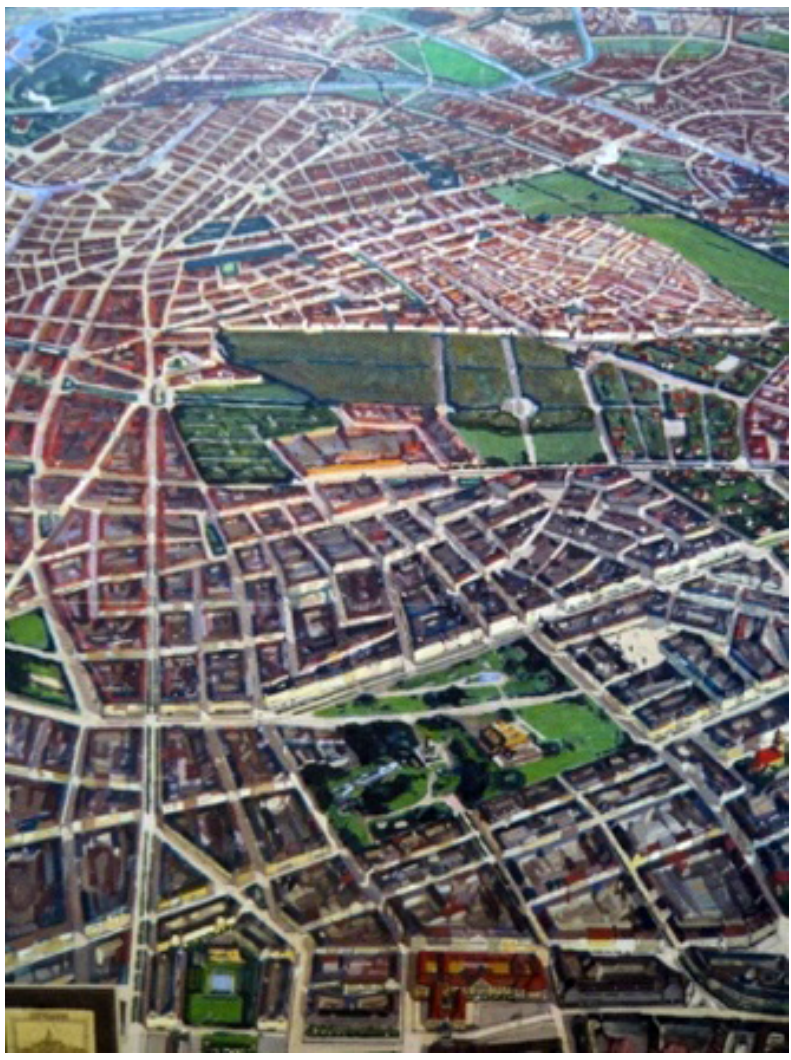

Figure 1. 1908-1910 Groß Berlin competition, A. Gessner. Perspective from the Südbahnhofstraße to the Müggelsee. Source: Tubbesing (2018).

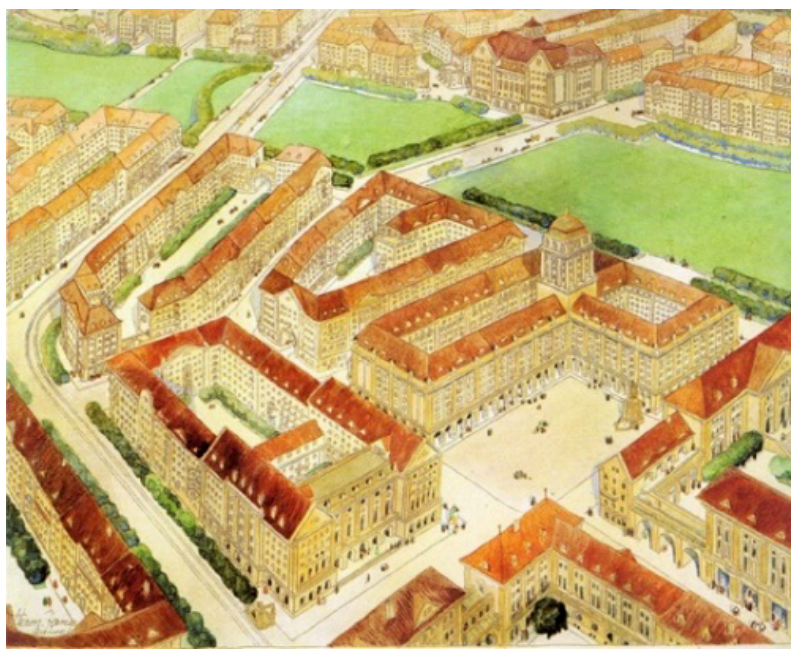

Figure 2. 1910 Greater Berlin competition, H. Jansen. Aerial view of proposed development, Tempelhofer Feld. Source: Tubbesing (2018). 


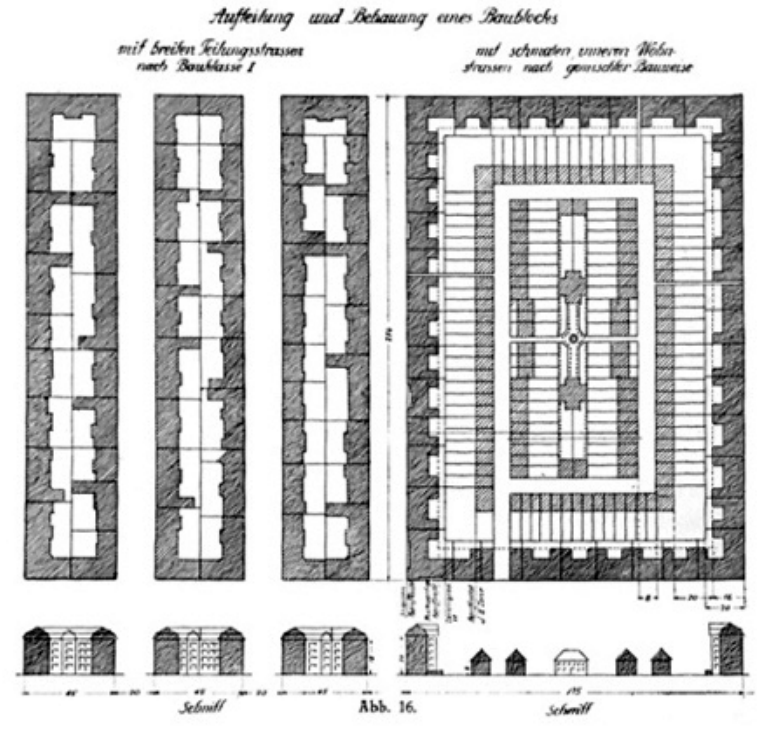

Figure 3. 1910 Groß Berlin competition, B. Möhring, R. Eberstadt, R. Petersen, 1910, Subdivision and construction of a building block. Proposal for mixed housing typologies. Source: Wettbewerb Gross-Berlin (1910).

Also the urban expansion of Hobrecht's plan for Berlin, strongly criticized since its approval in 1862 and then drastically planned in the 1920s (Arminius, 1874;
Bruch, 1870; Hegemann, 1930; Voigt \& Geldner, 1905), has been re-evaluated since the 1960 s and definitively rehabilitated by the most recent studies shifting the focus from the ideological dimension to that of the urban and spatial values that characterize it (Bentlin, 2018; Bernet, 2004; Bodenschatz, 1987; Dolff-Bonkämper, Million, \& Pahl-Weber, 2018; Geist \& Kurvers, 1980; Lubowitzki, 1990; Strohmeyer, 2000).

Similar experiments of urban architecture characterize all the great European cities up to the 1920s and 1930s in parallel to suburban settlements (Porotto, 2018; Sonne, 2014; see Figures 4 and 5).

The two models coexist with different outcomes and objectives, both fundamentally linked to the presence of the historical city, of which they represent the completion or the overcoming, but never the negation [Incidentally, in Giedion's book, Das neue Frankfurt and Ernst May are dismissed in a few sentences without images (Giedion, 1941, p. 477).

The real crisis of urban architecture occurs with the destruction and devastation of war post-war modernization. Here the urban dissolution process is programmatic and radical, above all where-as in Frankfurt or Berlin-the ancient city had disappeared and, together with it, its counterweight of history and memory, replaced by a kind of peripheralization of the center. The problem is, therefore, not constituted by Ernst May's

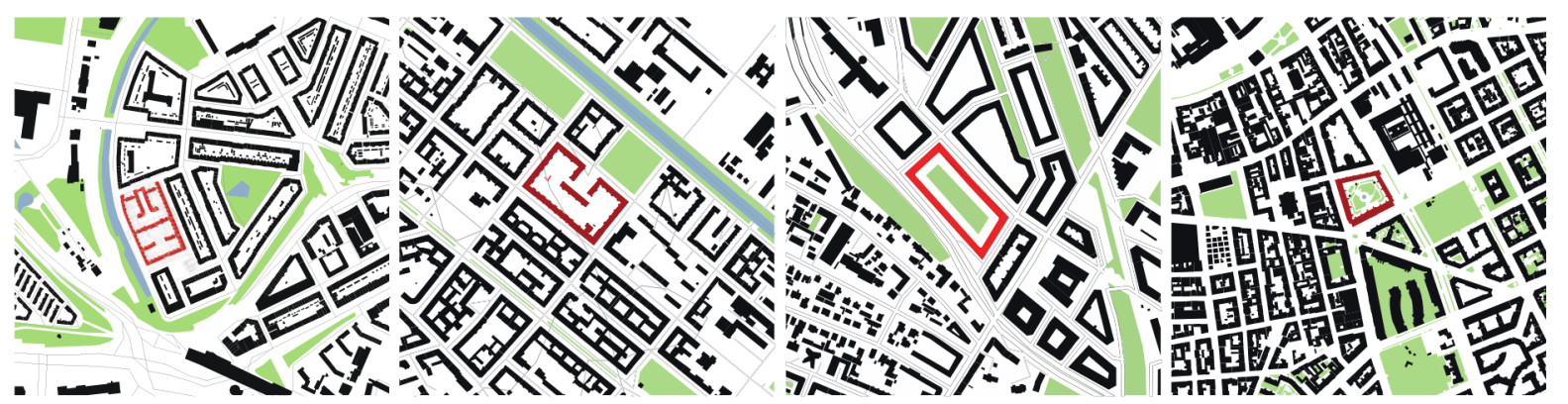

Figure 4. Drawings of the Elemente der Stadtarchitektur course at Potsdam School of Architecture, winter semester, 2018-2019. From left to right: Michiel Brinkman, Justus van Effen Block in Spangen, Rotterdam, 1919-1921; Paul Mebes, Werrablock, Berlin, 1924-1926; Kay Fisker, Hornbaekhus, Copenhagen, 1922-1923; Karl Ehn, Bebelhof, Wien, $1925-1926$. Source: Redrawings by students at Potsdam School of Architecture, academic year 2018-2019, unpublished.

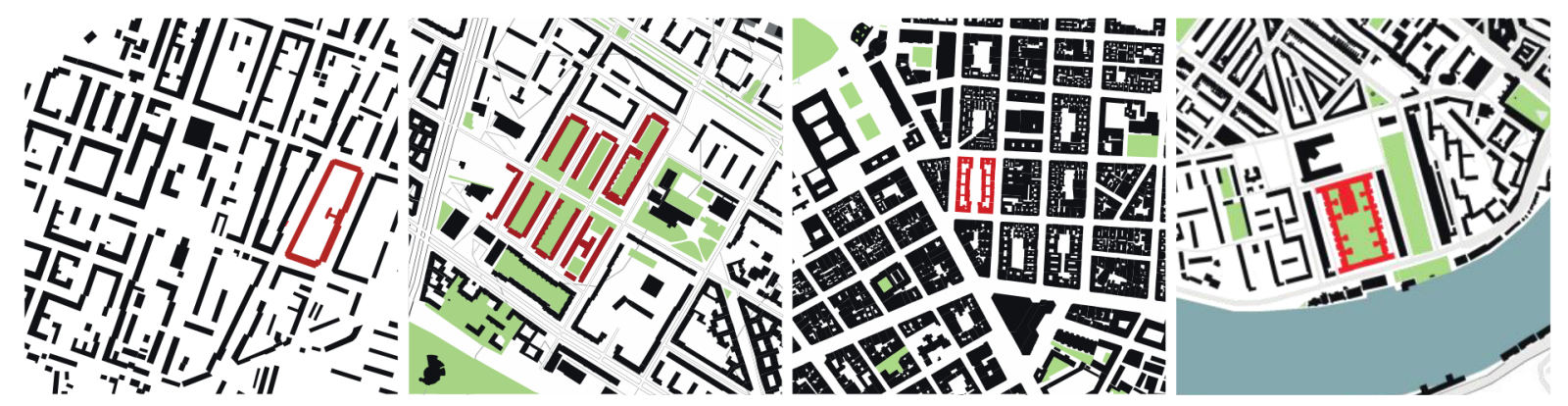

Figure 5. Drawings of the Elemente der Stadtarchitektur course at Potsdam School of Architecture, winter semester, 2018-2019. From left to right: Erwin Anton Gutkind, Sonnehof, Berlin, 1925-1927; Bruno Taut, Wohnstadt Carl Legien, Berlin, 1928-1930; Secundino Zuazo, Casa de las Flores, Madrid, 1930-1932; Stanley Gordon Jeeves, Dolphin Square, London, 1935-1937. Source: Redrawings by students at Potsdam School of Architecture, academic year 2018-2019, unpublished. 
Siedlungen in Frankfurt or Bruno Taut's in Berlin, but by the Großsiedlungen, the large estates of post-war reconstruction, whose radical anti-urban ideology also affect the city centers. At the beginning of the 1960s, Dietrich Wilhelm Dreysse, an architecture student at that time, described his impressions of a visit to the Frankfurt Siedlungen accompanied by Ernst May in this way:

Although the apartments were small and the motorization streets in no way increased, the settlements appeared cheerful and cosmopolitan-the opposite of what is offered us the eye in many post-war settlements. We recognized the real qualities, at that time just felt, later by comparing them to the large estates of the 60 s (also planned by May): the accentuated design of the public space, the mutual linking of social and formal projects, the intensive connection of city, house, and nature as well as and the appropriability of the spaces. (Dreysse, 2001, p. 3)

The comparison with the huge residential settlements built after the WWII is essential to focus on the problem: At the mere juxtaposition of Siedlung and Stadtquartier (housing estate and urban neighborhood), the problem of the loss of the historical city center and the question of scale are added. In a car-oriented city, low density takes the place of the high density, buildings are located according to functional principles and are not oriented towards public space, an undefined public space replaces the clearly structured collective places surrounded by buildings, monofunctional large estates deny social and functional diversity, repetition becomes the paradigm instead of variety, the address no longer has any relation to the identity of a place but is like a combination of coordinates on a chessboard and requires instructions to be found. The large-scale settlement replaces the urban district, the center becomes the periphery (see Figure 6).

\section{Theoretical References}

As a reaction to these interventions and to the loss of identity of European cities, the discussion on urbanity is resumed in the 1960s. Italian architectural culture plays an important role in this debate, thanks to an early awareness of the consequences produced by the dissolution of the city, operated by modern urbanism and of the problems of post-war reconstruction at the urban scale. It is interesting to note that this reflection develops clearly on a cultural axis of mutual influence between Italy and Germany, where Germany represents the most advanced position of modern architecture on a theoretical level and at the same time the most dramatic position in terms of post-war reconstruction. It is, therefore, no coincidence that much of the Italian debate of the sixties and seventies had to do with German architecture before and after the war, so this discussion could be defined as an Italian-German discourse on the rebirth of urban architecture.

Recall Ernesto Nathan Rogers's commitment in the name of continuity, i.e., of the impossibility to think about the current state of architecture without directly dealing with its past, ancient and recent. At that time, in the late 1950s and early 1960s, continuity basically meant revision of (North European) modernism: overcoming the dogmatisms of naive functionalism and orthodox rationalism, but also of the many ideological prejudices that hindered a serious critique of architecture in the second post-war period, starting from the reconnection with the broken thread of history. In particular, the years of Rogers's direction of the magazine Casabella, from December 1953 until January 1965, are decisive. The magazine was renamed, not surprisingly, Casabella-Continuità and themes such as the memory of places, the meaning of cities, the reality of architecture, and the character of buildings return to the agenda (Rogers, 1968). Thanks to Rogers and the young collaborators of the editorial staff-among others Vittorio Gregotti, Guido Canella, Aldo Rossi, and Giorgio Grassi-a new focus on the rational dimension of architecture and its constitutive essence as an urban phenomenon emerges along with the critical reading of international modernism.

The outstanding production of publications dedicated to the theme of the city and urban architecture in those years reflects the depth and richness of this debate. I refer here, as an example, to the titles appearing in the two book-series, respectively by the publisher Marsilio (Padua) and by the publisher Officina (Rom), which covered the span of a decade between the mid-sixties and the mid-seventies, summarizing the extremes of the debate (see Figures 7 and 8). Titles such as L'architettura della Città (The Architecture of the City) by Aldo Rossi
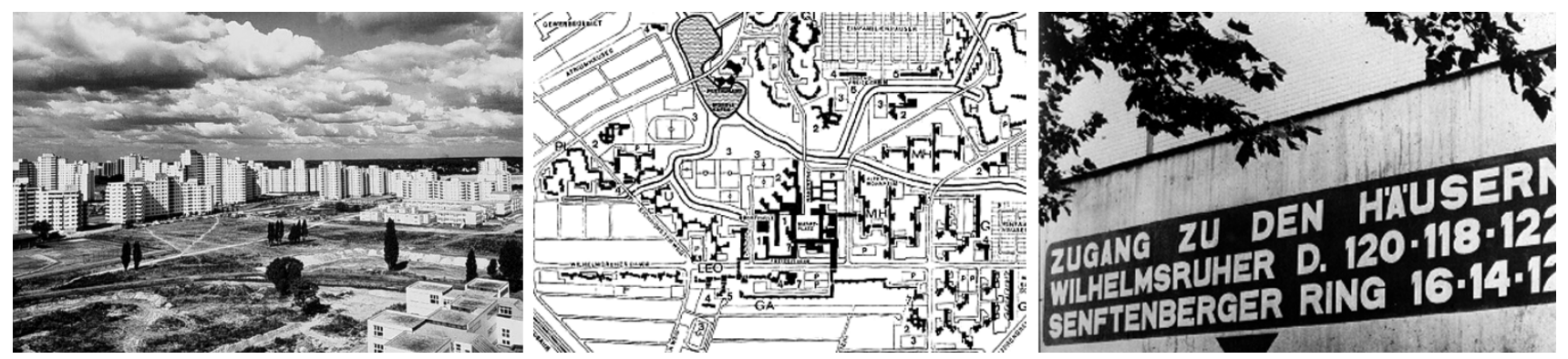

Figure 6. The post-war car-oriented city in Berlin: Märkisches Viertel. Source: Wilde (1989). 


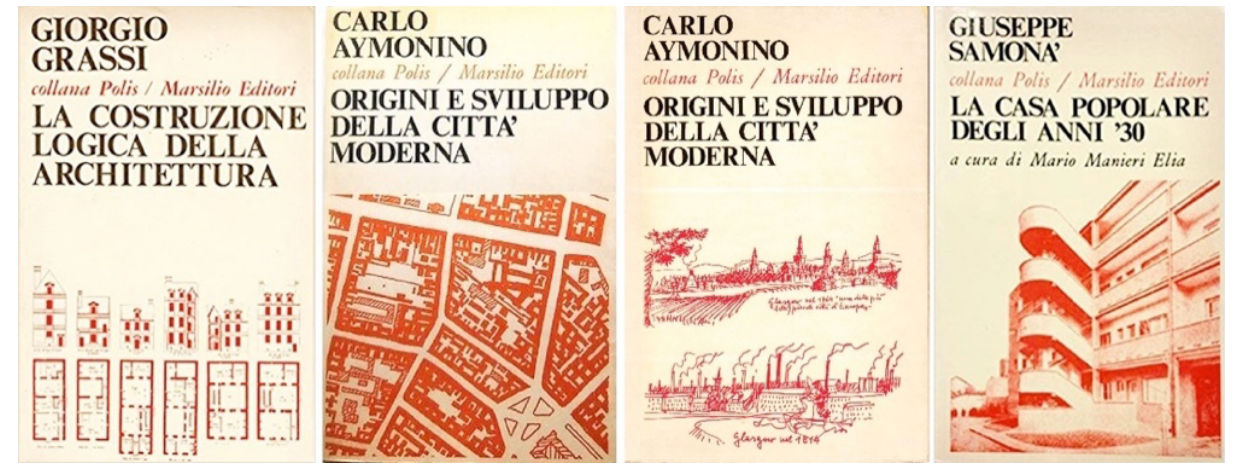

Figure 7. Publications dedicated to the theme of the city and urban architecture. From left to right: Giorgio Grassi, La Costruzione Logica dell'Architettura (The Logical Construction of Architecture), 1966; Carlo Aymonino, Origini e Sviluppo della Città Moderna (Origins and Development of the Modern City), 1971 and 1975 (2nd edition); Giuseppe Samonà, La Casa Popolare degli Anni 30 (Social Housing in the 1930s), 1972.
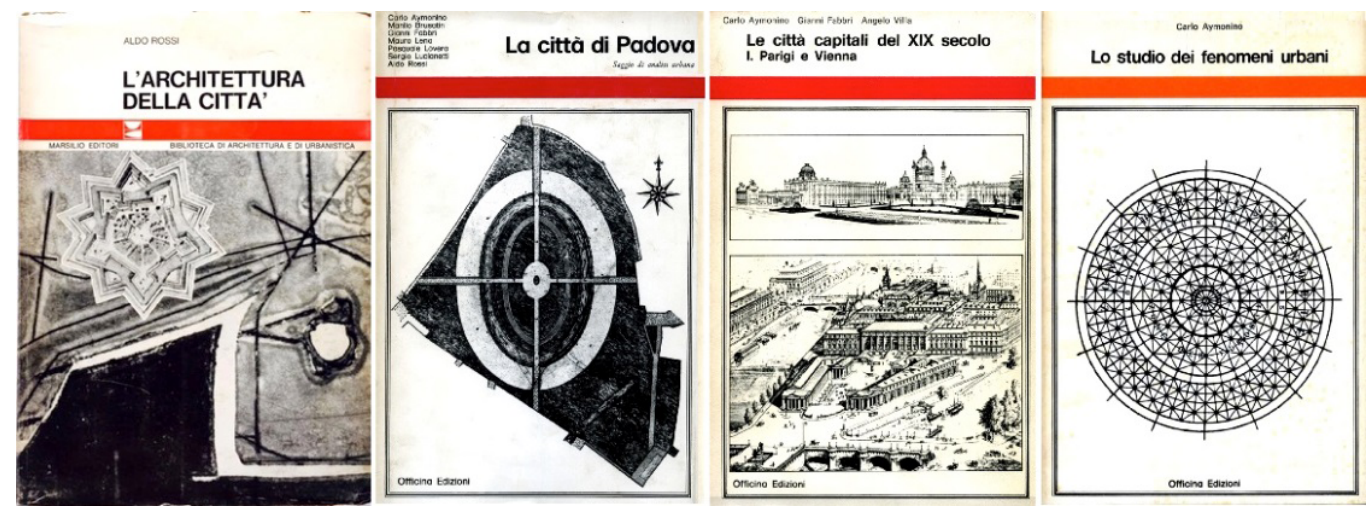

Figure 8. Publications dedicated to the theme of the city and urban architecture. From left to right: Aldo Rossi, L'architettura della Città (The Architecture of the City), 1966; Carlo Aymonino, La Città di Padova (The City of Padua), 1971; Carlo Aymonino, Le Città Capitali deI XIX Secolo (The Capital Cities of the Nineteenth Century), 1975; Carlo Aymonino, Lo Studio dei Fenomeni Urbani (The Study of Urban Phenomena), 1977.

(1966) or Origini e Sviluppo della Città Moderna (Origins and Development of the Modern City) by Carlo Aymonino (1971a), bring the theme of the city back to the core of the debate on architecture, emphasizing the centrality of housing in the construction of the city, its role as an element of "norm" and "normality" in the definition of the urban form. Two of these books, in particular, refer to Frankfurt, Carlo Aymonino's L'abitazione Razionale (Rational Dwelling), dedicated to the CIAM of 1929 (Aymonino, 1971b) and Das Neue Frankfurt 1926-1931, by Giorgio Grassi, dealing with a critical analysis of Ernst May's magazine in the light of the post-war theoretical reflections on architectural typology and the relationship between architecture and city (Grassi, 1975; see Figure 9).

In these books, the reflection on the historical city is critically intertwined with the projects of the modern city, in the attempt to find the experiences that reproduce the complexity of the European tradition: Hausmann's Paris, the Red Vienna, Fritz Schumacher's Hamburg, Berlage's Amsterdam or Oud's projects for Rotterdam. Also, the Siedlungen of Frankfurt, with those of Taut in Berlin, are included in the positive examples alongside the properly urban models:
Between 1925 and 1930, Frankfurt, along with a few other cities, with the experience of the Siedlungen and the entire structure of the city, is in the center of Europe. Just as the Germanic area in those years is where the limits of architectural and artistic debate in general are renewed, cities like Hamburg or Berlin, like Stuttgart or precisely Frankfurt, are the benchmarks
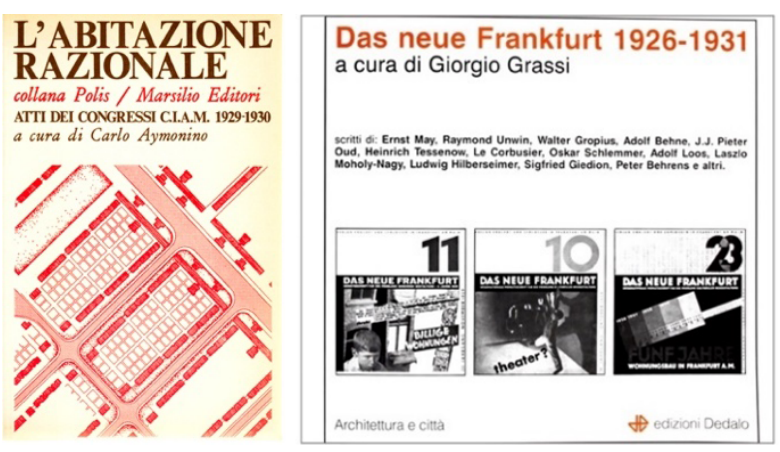

Figure 9. The definition of urban form: Frankfurt. From left to right: Carlo Aymonino, L'abitazione Razionale ( $R a-$ tional Dwelling), 1971; Giorgio Grassi, Das neue Frankfurt 1926-1931 (The New Frankfurt 1926-1931), 1975. 
for the new architecture and develop the most original and important idea of the city at that time. (Grassi, 1975 , p. 10)

It could, therefore, be said that this discussion in a sense starts precisely in Frankfurt and inextricably intertwines theories and realizations in an overall reflection on the problem of designing the city. In the writings of Aymonino, Rossi and Grassi, the names of Stübben (1890), Eberstadt (1909), Baumeister (1911), Scheffler (1913), Brinkmann (1920) or Wolf (1919) recur, in an attempt to reconnect the concrete tradition of the European city with the treatises and manuals, that is, with those attempts to codify the constituent elements of architecture and the city, to deduce rules from reality and define methodologies for work. Through a historical analysis, these writings try not only to define a city theory, but also to provide the outlines of a design methodology.

\subsection{Methodology}

A central element regarding the present reflection on urban architecture is represented by the question of the ground issues and ground parcellation. This is a topic that is present throughout the manuals of urban design and in particular in Eberstadt (1909), to which the famous and quoted study by Hans Bernoulli Die Stadt und ihr Boden (The City and its Ground) refers (Bernoulli, 1946). The question of land ownership, parcels and, essentially, the division between public and private in the construction of the city becomes the cornerstone of both theoretical reflection and architectural methodology (see Figure 10).

Starting with these studies, since the end of the 60s, the reflection is based more and more on a typological and morphological approach to the problems of architecture and the city, leaving in the background the ideological issues, which are those that still today, in fact, inspire the supporters of the legacy of post-war urban planning. In particular, the graphic tool of the typological survey of the ground floors, introduced by Muratori $(1960,1963)$ and widely used by Rossi and Grassi, highlights the close link between ground division and buildings and therefore between architectural typology and urban morphology (see Figure 11).

As a second instrument-almost complementary to the typological plan of the ground floors in the graphic
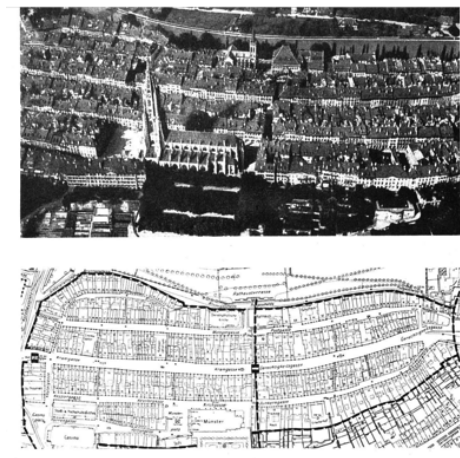
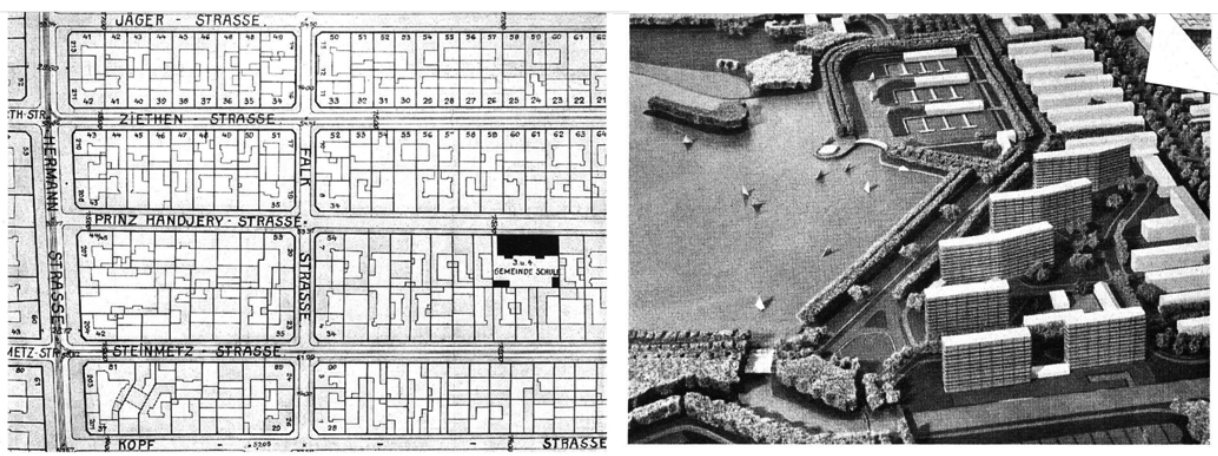

Figure 10. The city and its ground. From left to right: Zähringer foundation, Bern, scope of the plan from 1291 and of the first enlargement; an area with five-storey building construction, Berlin-Neukölln, house after house treated as a single building task, completed by 25 meters high firewalls against the neighbors; Amsterdam. Source: Bernoulli (1946).
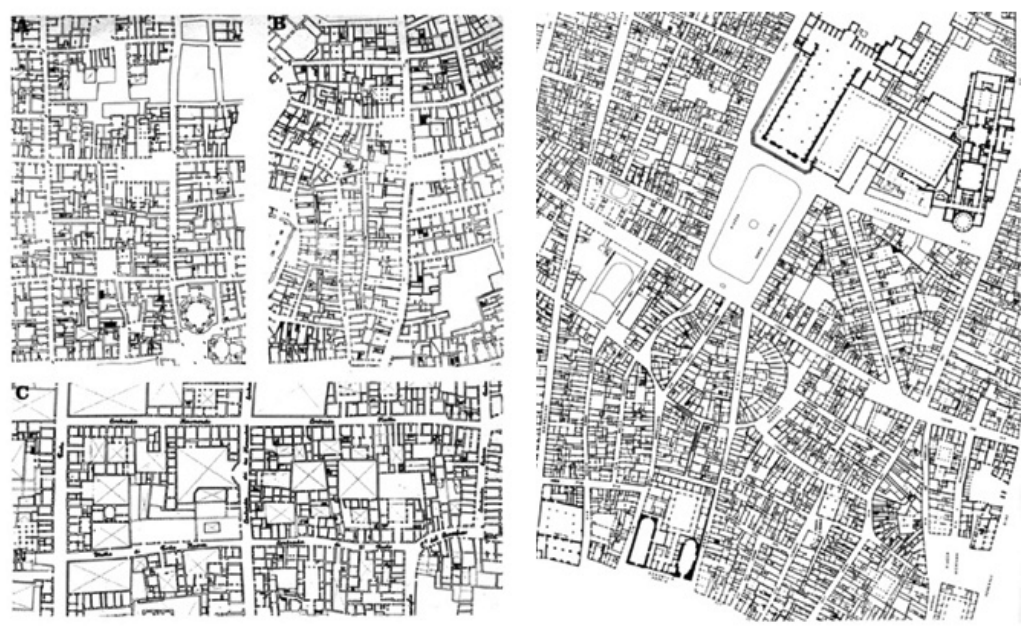

Figure 11. The typological survey of the ground floors. From left to right: Saverio Muratori, wall surveys in Genoa and Como (Muratori, 1963); Aldo Rossi, typological survey of the S. Croce district in Florence (Rossi, 1966). 
reading of urban fabrics and in the interpretation of the relationship between private and public, architecture and city-the solid-void plan is also introduced in the 1970s, becoming canonical with the book Collage City by Rowe and Koetter (1978). The solid-void plan shows, as a Gestalt diagram illustrating the fluctuations of the figure-ground phenomenon, that the city of modern architecture is, in every way, so much the opposite of the traditional city that:

The one is almost all white, the other almost all black, the one an accumulation of solids in a largely unmanipulated void, the other an accumulation of voids in a largely unmanipulated solid; and, in both cases, the fundamental ground promotes an entirely different category of figure-in the one object, in the other space. (Rowe \& Koetter, 1978, p. 62)

This form of drawing, used by Colin Rowe to interpret the relationship between buildings and public space in the

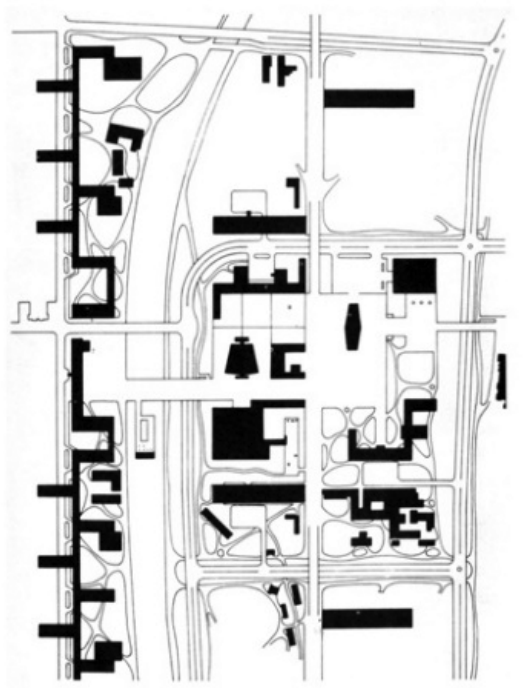

city becomes the privileged reading tool for destructions and functionalist reconstructions after WWII, showing with absolute evidence the contrast between textures and built objects (see Figures 12, 13 and 14).

In the seventies, this discussion develops internationally and the problem of contemporary urban design overlaps in a single discourse with that of reconstruction, first on the theoretical level and then on the level of projects and architectural achievements. On the one hand, the awareness of the loss of urban space in the urbanism of the 20th century emerges dramatically and on the other, the need for the reconstruction of destroyed urban spaces is imposed (Krier, 1975). In the German experience, in particular, construction and reconstruction are intertwined in an indissoluble bond. As a paradigmatic example, we can mention the debate on the urban block, inaugurated by Joseph-Paul Kleihues in 1977 with the construction of block 270 at Vinetaplatz in Berlin and assumed as a paradigm of the international debate (Kleihues, 1978, 1979; Lotus International, 1978).

Figure 12. Modern city versus traditional city: Le Corbusier's project for St. Dié and the historical city center of Parma. Source: Rowe and Koetter, 1978.

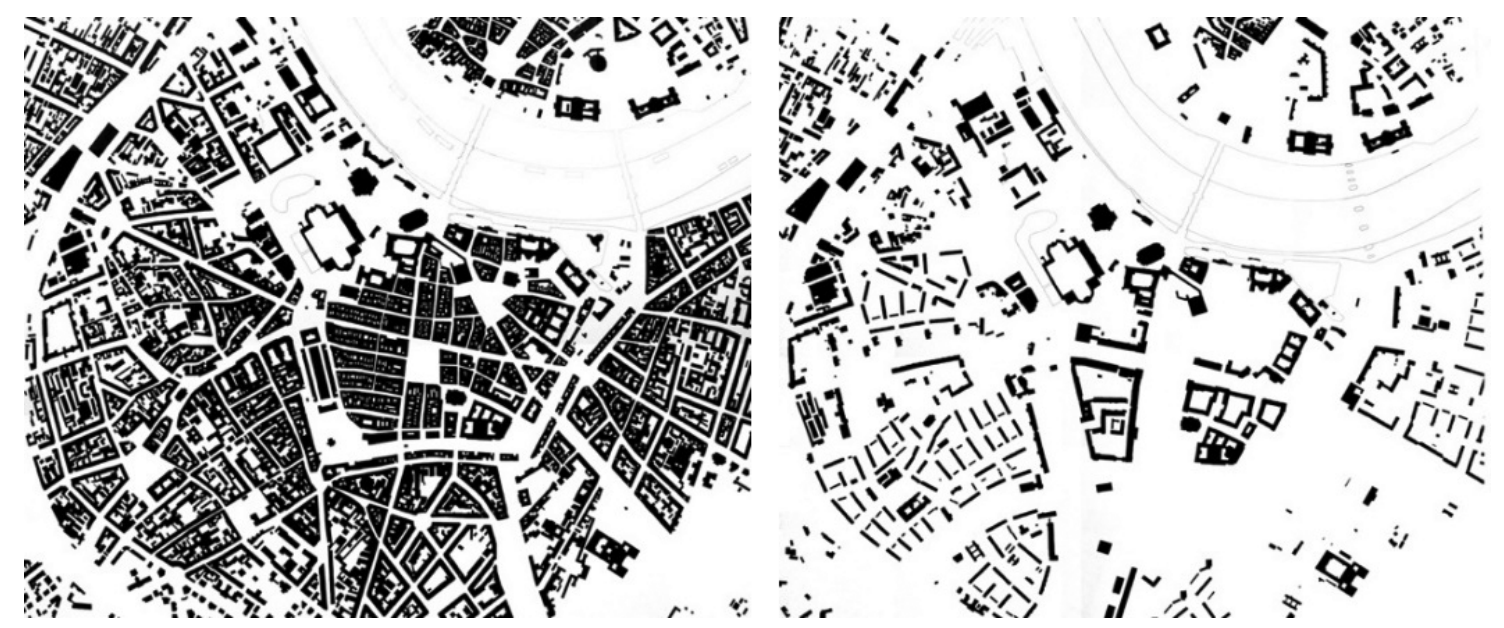

Figure 13. Before and after the war: Solid-void plan of the city center of Dresden. Source: Curdes (1993). 

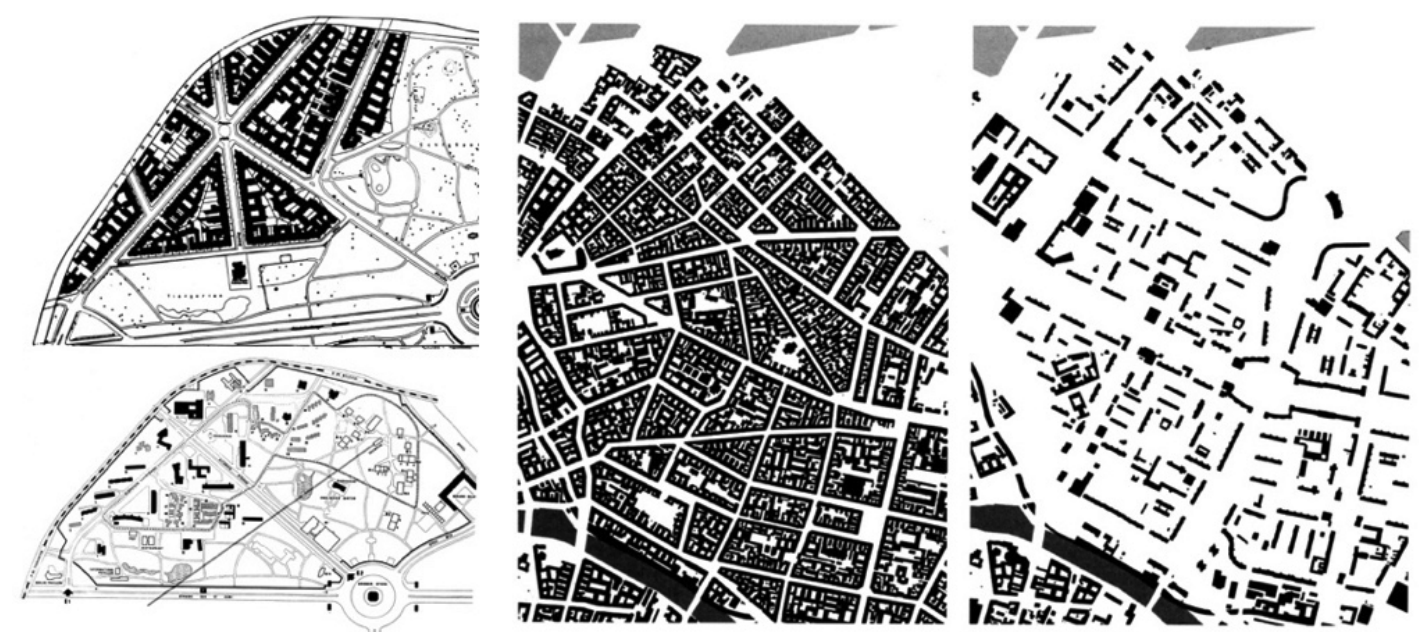

Figure 14. Traditional city versus post-war city: Hansa Viertel and Stalin-Allee (today Karl-Marx-Allee), Berlin. Source: Stimmann (2002).

Furthermore, the Internationale Bauausstellung Berlin (IBA; the International Building Exhibition), 1984-1987, section Neubau ("new building"), under the direction of Joseph-Paul Kleihues, proposes that "the historical basic structure of the city must become the fundamental constant for urban development" (Senator für Bau- und Wohnungswesen, 1978, pp. 3-4; see Figure 15).

The historical memory of the city joins here with the research on housing types and the theme of the urban block develops in parallel with the investigation on the architectural typologies that can compose it (Kleihues, 1973a, 1973b). However, even the IBA clearly shows the typical post-war problem of a city built exclusively through housing without any functional and social mix: a city without owners and without monuments (Rowe, 1984).

Despite this, thanks to the close relationship between historical city and project, between urban morphology and architectural typology, the IBA as an overall experience can once again be linked to the tradition of manuals for urban design, of the works that try to systematize the knowledge of the city in order to define a design methodology. An operation similar to that carried out by Ernst May-the magazine Das neue Frankfurt can be read as "an architectural handbook deduced and constructed starting from the city itself" (Grassi, 1975, p. 10)-or to the more recent critical revision of the urban planning theory of the last century (Magnago Lampugnani, Albrecht, Bihlmaier, \& Zurfluh, 2017), accompanied by the type-morphological and architectural analysis of the examples of history (Magnago Lampugnani, Stühlinger, \& Tubbesing, 2018).

Going back to the initial research-question, the difference between Siedlungsbau and Städtebau, between the suburban housing estate and the urban neighborhood as a constituent element of the debate on the European city, it is possible, in light of these reflections and examples, to analyze some projects starting from morphological and spatial elements to define reference points for a future-oriented methodological discussion. Frankfurt, with the two diametrically opposed examples of Das neue Frankfurt and the Dom-Römer, can be seen as the framework for this debate.

\section{The Reality of the City}

\subsection{Das neue Frankfurt}

In the brief period from 1926 to 1930 , the majority Social Democrat-led city government in Frankfurt tried to thor-

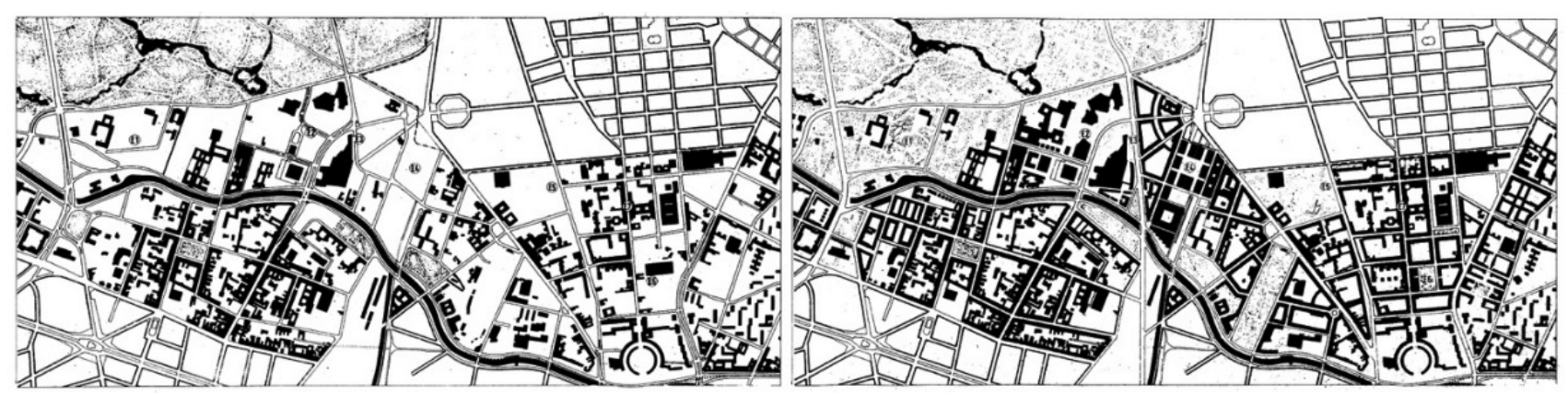

Figure 15. IBA Berlin: Solid-void plan, actual state at the time and proposed design. Source: Kleihues (1981). 
oughly modernize the city and society. The essential conditions for the realization of this ambitious project were a good political direction and a good housing policy, guaranteed respectively by Ludwig Landmann as Mayor and Ernst May as almighty deputy for the entire construction industry:

What was the new Frankfurt? First and foremost, it was a housing program designed to eliminate the material and cultural housing shortage....But it was also a new spatial organization of the city, a zoning plan whose basic ideas are still visible in the city today: industrial zones along the Main and railways; a cultural and administrative center in the city center; Reduction of the population in the inner city and settlement of the surrounding area in suburban housing estates and satellite towns; Urban green areas with promenades, public parks, sports facilities, agricultural green, and finally a hierarchical network of traffic routes with trams and highways. It was also an attempt to convey new and emancipatory social and cultural behavior through a new idea of living in the city. (Dreysse, 2001, p. 3; see Figure 16)

The two most important themes of the experience of Das neue Frankfurt are: the conception of an overall plan for the whole city, of which the new Siedlungen are a part, and the idea of the house as a basic unit that embodies the modern idea of living. In this context, the initiative of a monthly magazine dedicated exclusively to the new Frankfurt-Das neue Frankfurt, 48 issues between 1926 and 1930-should be read as an attempt to scientifically document the experience in an urban design manual: from the idea of the plan (the satellite cities) to the idea of satellite (the Siedlung), from the idea of Siedlung (the Anger, settlement around a collective space) to the single house (Existenzminimum; Michieletto, 2008). These are the elements that still make Das neue Frankfurt a positive reference.

The core of the discussion on the new Frankfurt-and the topic of the CIAM of 1929-is however at the scale of the house, in the name of the Existenzminum. The aim was to design the typical house for the typical family, the space of which was intended to organize daily life in all its details. In this sense, the new Frankfurt was a success: quantity $(12,000$ apartments built in five years), quality and price of housing. The strategy: rationalization, standardization, prefabrication and typification.

From the point of view of architectural design, the new Frankfurt found its most visible expression in the uncompromising shape of its buildings and everyday products: break with the past in line with the aesthetics of classical modernism, no ornament, the authentic form, pure materialization of contemporary production that reflects the reality of the new way of life. In the combination of the elements there is an attempt to create visual axes and spatial sequences, but just for the first period until 1929. Later, the repetition of absolutely equal individual elements has become the rule (see Figure 17).

Despite the heroic dimension of the new Frankfurt operation, and in comparison with other contemporary experiences of mass housing, such as that of Vienna (Porotto, 2018), the analysis shows that at all these three different scales (city/settlement/house), three types of problems are generated concerning the urban character of the Siedlungen: dependence from the city center, monofunctionality, undefined public space and lack of identity. The same problems that Ernst May's postwar production in the field of housing estates presents in an amplified and dramatic manner, as shown by the retrospective exhibition organized by the Deutsches Architektur Museum in 2011 on the occasion of the architect's 125th birthday (Quiring, Voigt, Cachola Schmal, \& Herrel, 2011).

\subsection{Dom-Römer}

Ironically, just as Ernst May's Siedlungen became again the center of discussion for the 90th anniversary of the 1929 CIAM with a new exhibition at the Deutsches Architektur Museum - which, as is already evident in the title, "New Human, New Housing", underlines the avant-garde dimension of the social project (Voigt, Deschermeier, \& Cachola Schmal, 2019)-the city of Frankfurt returned to international attention thanks to a project related to housing and the city, which repre-
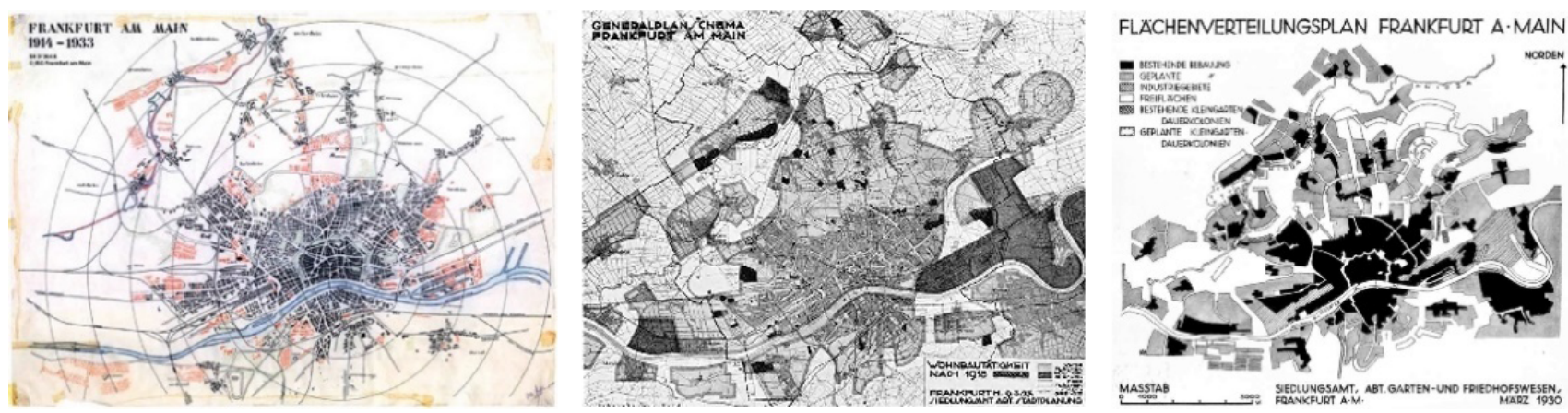

Figure 16. Frankfurt am Main. From left to right: housing construction 1914-1933; general construction plan after 1918; surfaces distribution plan of 1930. Source: Porotto (2018). 


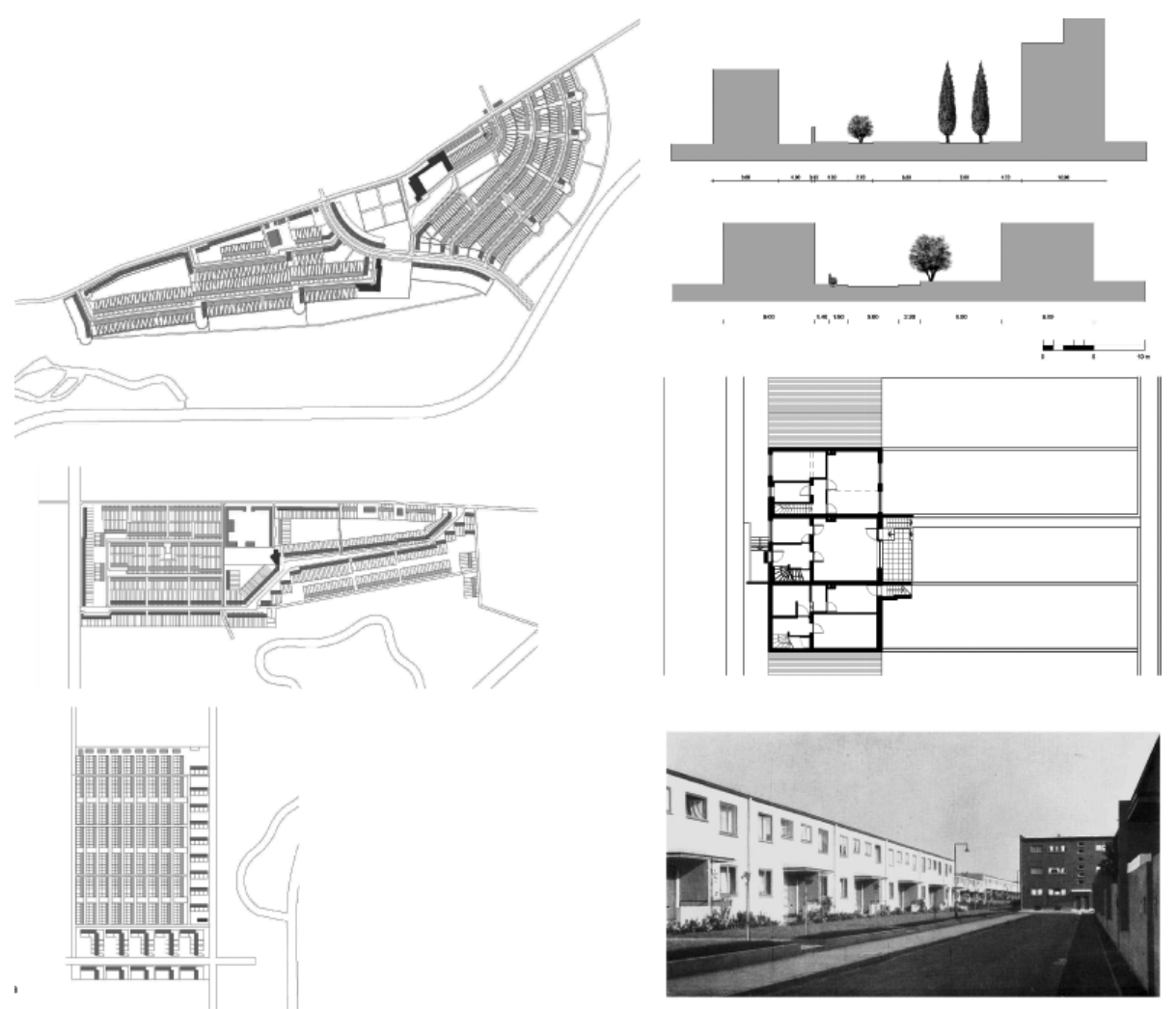

Figure 17. Frankfurt am Main. Left, from top to bottom: Site plan of the Siedlungen Römerstadt, Praunheim and Westhausen. Right, from top to bottom: Cross section of Hadrianstraße and Am Burgfeld in the Siedlung Römerstadt; floorplans of the house types A and D of Im Burgfeld; photo of the street. Source: Michieletto, (2008).

sents, however, the opposite of the experience of Das neue Frankfurt: the Dom-Römer "reconstruction".

The contrast between the two cases could not be more evident. In the heart of the historical city, between the Dom and the Römer, the two symbolic places of origin of the city, the war and post-war destructions generated that tabula rasa that allowed the creation of a fragment of the modern city. The Technical Town Hall built symbolically in this historical place is its manifesto: an out-of-scale megastructure, with a huge underground parking garage and a metro station, regardless of the historical parcels and the surrounding urban fabric, celebrating efficiency, functionality, and the new construction techniques. In the early 2000s, the city of Frankfurt decided to demolish this building and rebuild the historic city (see Figure 18). After the first competition in 2005, won by KSP Jürgen Engel Architekten, there was, within the framework of a heated political discussion, the decision to embark on a project which fully reproduces the historical structure of the city. In 2009 the Dom-Römer $\mathrm{GmbH}$, a company of the Frankfurt municipality, was founded, a new competition was announced and in 2018 a new residential and commercial district was inaugurated (Sturm \& Cachola Schmal, 2018).

Regarding mass public housing, with minimal individual dwelling cells and standardized construction conceived by Ernst May, an equally public intervention is now opposed, but with a few individual houses and
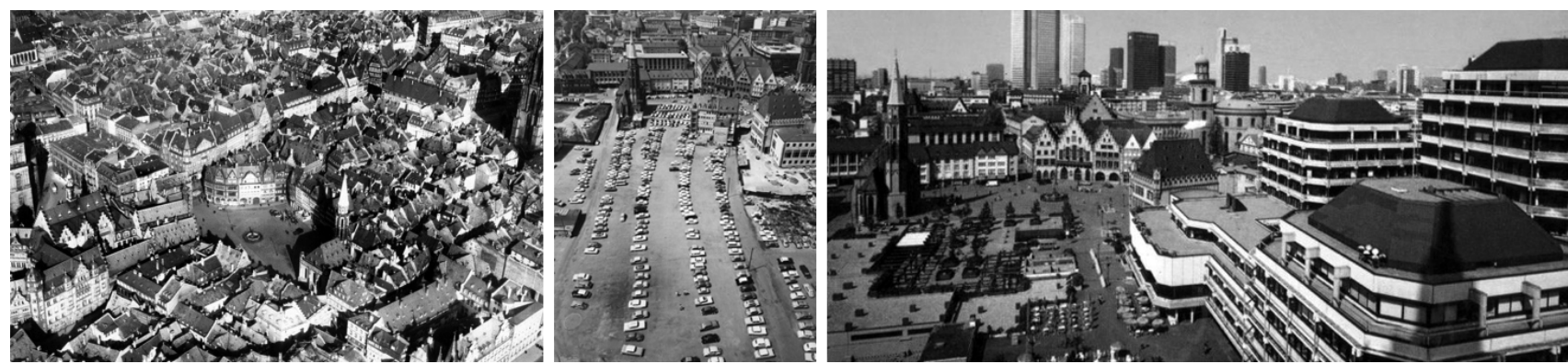

Figure 18. Frankfurt am Main: The old city. From left to right: Historical city center, Frankfurt am Main; Aerial view, 1936; Dom-Römerberg-Area, view from the Cathedral, 1961; the Technical Town Hall, 1985 ca. Source: Sturm \& Cachola Schmal (2018). 
owned apartments for upper-middle-class customers, unique in their exceptionality, constructed with traditional techniques and finished with craftsmanship, case by case. The modernistic idea of low-density monofunctional satellite neighborhoods on the edge of the consolidated city, based on the repetition of typed elements and on the correct orientation of buildings in order to grant air and light, at the expense of a clear definition of public space, is replaced today, in the core the city, by the medieval plan, with its irregular parcels and narrow, winding dark alleys, high density and multifunctional buildings, with a strongly characterized public space. The positions are, of course, diametrically opposed also with respect to the roof dispute, which in the 1920s animated architects: strictly flat roofs in the new Frankfurt of the 1920 s and pitched roofs in the gabled houses of the ancient contemporary Frankfurt (see Figure 19 and 20).

The characteristics of a high-density multifunctional urban neighborhood are evident and have convinced even the most skeptical critics. Nevertheless,
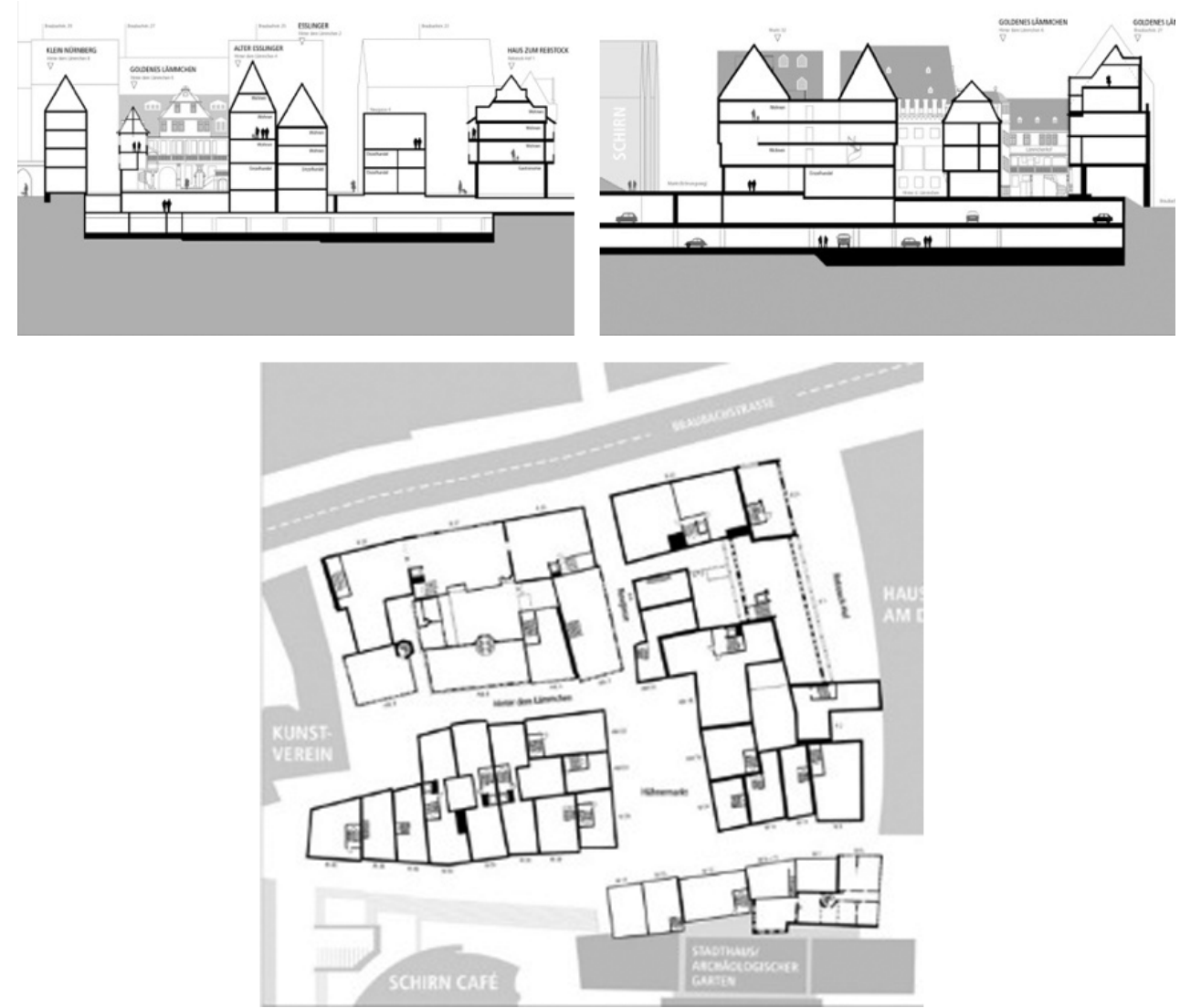

Figure 19. Frankfurt am Main. Top: Dom-Römer, sections; bottom: Dom-Römer ground-floor plan. Source: DomRömer (2011).
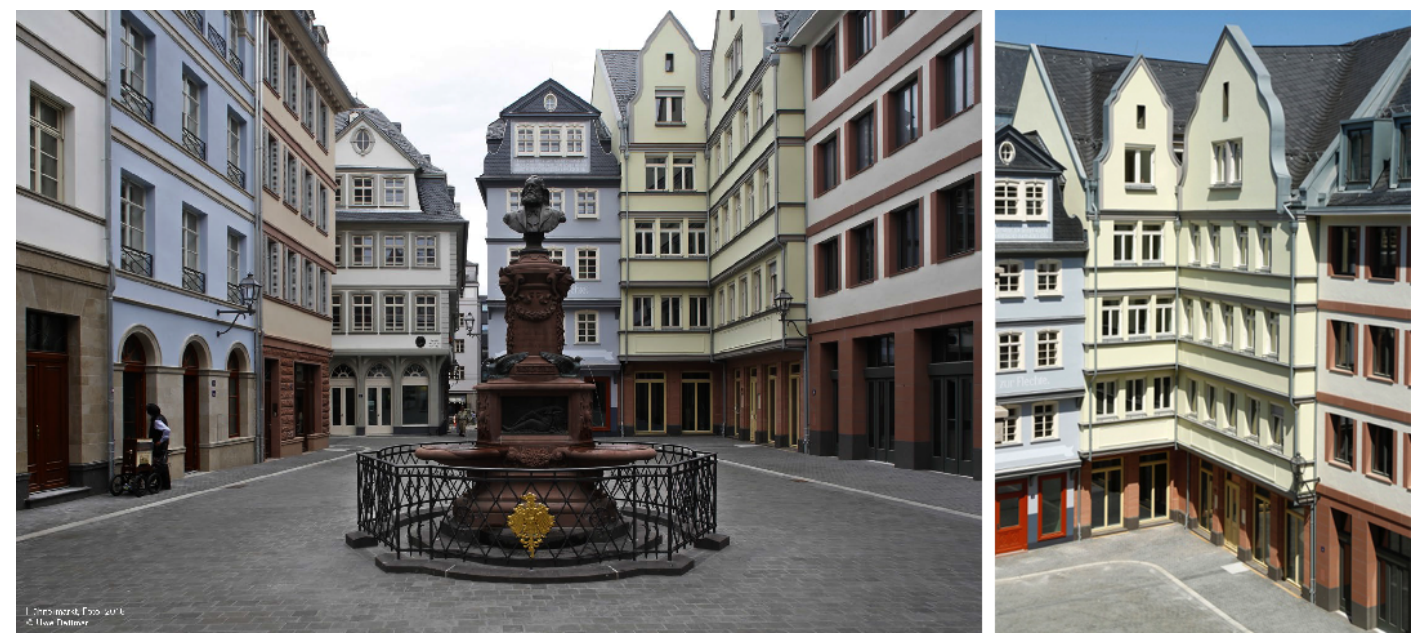

Figure 20. Frankfurt am Main: The new Dom-Römer district. Source: Sturm \& Cachola Schmal (2018). 
the rules imposed by the design advisory committee (Gestaltungsbeirat) and the number of philological reconstructions in relation to the amount of new buildings do not clear the field from the doubt of an "historical falsification" or an "architectonical fiction". Above all, the question arises regarding the repeatability of such an operation, of its validity on a larger scale, of the possibility of bringing its principles back to a general form: the form of a manual for the contemporary design of an urban neighborhood. This project is the right solution for this place, but it is not a program, nor is it meant to be.

\subsection{WerkbundStadt am Spreebord Berlin}

The case of the WerkbundStadt am Spreebord in Berlin, on the contrary, represents, or rather could have represented-the project is unfulfilled-the answer to this question and a valid proposal with respect to the dialectic between Sidelungsbau and Städtebau in general. The project, conceived by the Berlin section of the Werkbund in 2014, under the chairmanship of Paul Kahlfeldt and then of Claudia Kromrei, was aimed-in the tradition of the historic association of architects, artists, and industrialists, founded in München in 1907 that radically questioned the idea of housing between the two wars (Kahlfeldt, 2016) - to the realization of an exemplary housing project in response to the crucial questions of the contemporary era. Thus, not a Werkbund Siedlung, a low-density suburban settlement in the green, as in the 1920s and 1930s, but a high-density urban neighborhood in a central area of the city, the first Werkbund Stadt indeed: 1100 apartments for 2000 residents of different social backgrounds on just 2.9 hectares of an abandoned industrial area on the banks of the Spree in the Charlottenburg-Wilmersdorf district. The result was not the only aspect expected to be exemplary; so were the processes of conception and realization: collective, participatory, dialectical. A shared general plan, 39 building plots, 33 architects, an internal competition procedure, with the involvement of the owners of the area, the district technical planning office, residents, politicians, landscape architects, evaluators, and experts. After two years of work, coordinated and directed by the Berlin Werkbund through meetings and workshops, the WerkbundStadt Berlin project was presented to the public on 23 September 2016, with an exhibition, a conference, and a publication (Deutscher Werkbund Berlin, 2016; see Figures 21 and 22).

As described by Wolfgang Sonne in his essay (Sonne, 2016, p. 79), the project presented itself as the most advanced solution to the problem of the contrast between Siedlungsbau and Städtebau, with a ten-point program, aimed to research a design methodology based on morphological elements constituting the urban space: Clear definition of public spaces through the location of houses within the urban project, alignment of the houses on the street or square (each identifiable with its own house number) without any semi-public path or area, subdivi-
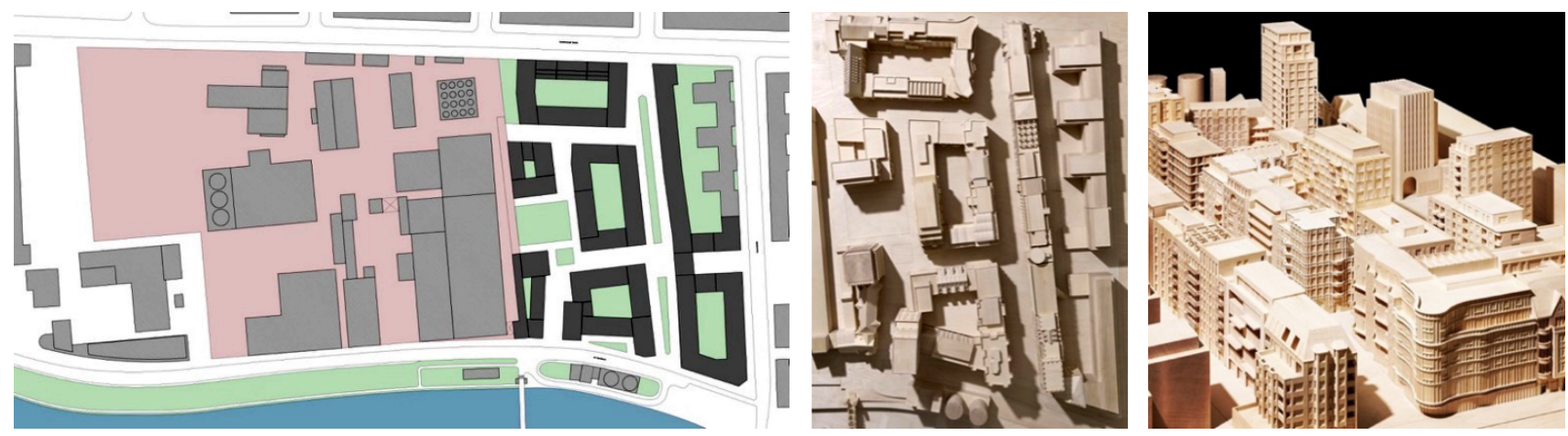

Figure 21. WerkbundStadt am Spreebord in Berlin. From left to right: masterplan; models. Source: Kahlfeldt (2016).
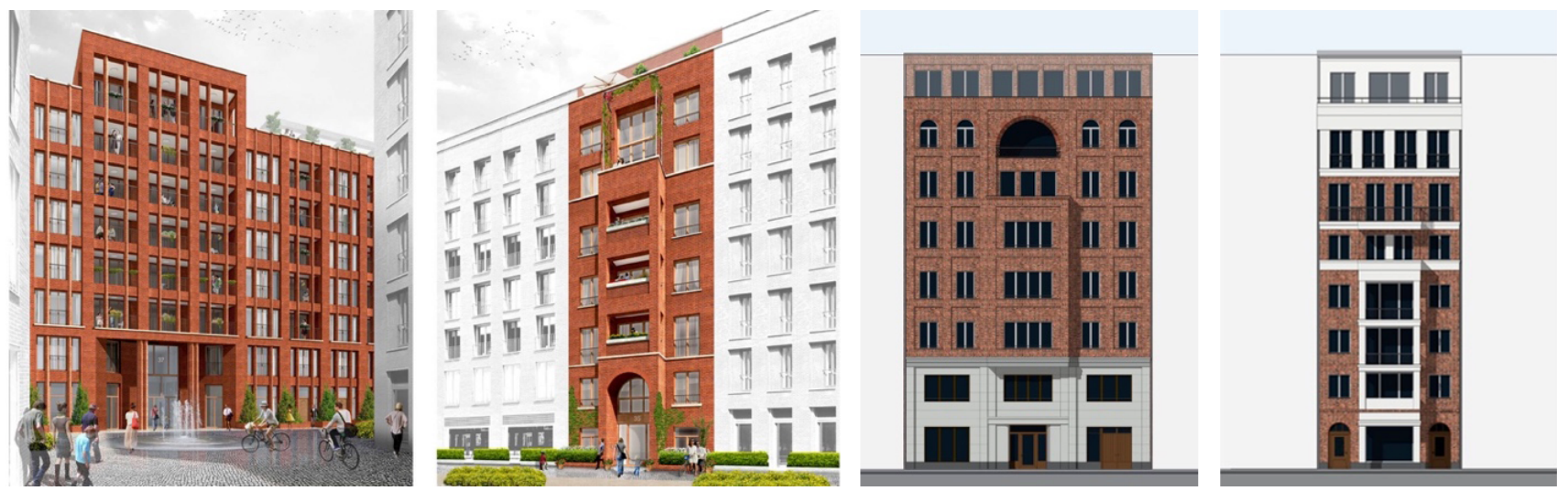

Figure 22. WerkbundStadt am Spreebord in Berlin, projects by Bernd Albers and Paul Kahlfeldt. Source: Kahlfeldt (2016). 
sion of the building into individual housing units with different types and cuts of apartments, configuration of front and rear elevations, each with the appropriate character, definition of common elements of individual houses at the scale of the neighborhood, integration of different functions on the ground floors, and creation of a neighborhood center with public buildings.

All of these elements can be traced back to the historic city, but they are also an integral part of the Leipzig Charter on sustainable European cities from 2007, which outlines the constituent features of the European city of the future:

An important basis for efficient and sustainable use of resources is a compact settlement structure. This can be achieved with spatial and urban planning, which prevents urban sprawl by strong control of land supply and of speculative development. The strategy of mixing housing, employment, education, supply and recreational use in urban neighborhoods has proven to be especially sustainable. (EU member states, 2007)

The reasons for the failure of this project-which we hope will find space elsewhere-are to be found in urban politics and in the real-estate market, but also in the unsolved node of contemporary urban design, divided between architecture and urban planning, between a technocratic urbanism and a morphological approach to the spatial problems of the city (Malcovati, 2018). From the point of view of the issue dealt with here, the urban architecture in European cities, the WerkbundStadt would have been able to represent the test bed of that idea of a dense, multifunctional, and formally articulated city, which has occupied the center of German architectural discussion in recent decades: a city based on the close relationship between street, block, and building plot.

This idea of the city is not just a formal idea: it also includes the attempt to adapt regulations and procedures to the needs of the present as well as the will to act on the economic mechanisms of realestate investments and on the relations between public and private in the construction of housing, according to the model that had already been tested in typological terms in Berlin at the end of the nineties with the Planwerk Innenstadt and the construction of the Townhouses district in Friedrichswerder (Senatsverwaltung für Stadtentwicklung, Umweltschutz und Technologie, 1997a, 1997b).

\subsection{Königsufer and Neustädter Markt, Dresden}

As the last example, I would like to mention the very recent competition for the Königsufer and Neustädter Markt in Dresden, the results of which were announced a few weeks ago (in February 2019) regarding the urban design of the historic neighborhood on the north bank of the Elbe. The presented projects cover the full spectrum of possibilities, from the most "modernist" solutions defined by a free configuration of architectural elements up to the literal repetition of the historical parcels structure, as in the Dom-Römer in Frankfurt. The winning project, by the architectural office of Bernd Albers, with Vogt Landscape Architects, represents an interesting balance between reconstruction and new construction, we could say between Dom-Römer and WerkbundStadt (see Figure 23).

From the project report:

The project offers Dresden a double chance to regain the banks of the Elbe with its significant townhouses on the Elbterrasse and at the same time to reactivate the baroque space of the Neustädter Markt....Thanks to the parallel shift of the historic building structure to the south, a neighborhood of independent houses can be built anew. The original structure is typologically assumed and architecturally reinterpreted....In sum, a new version of the city morphology succeeds,
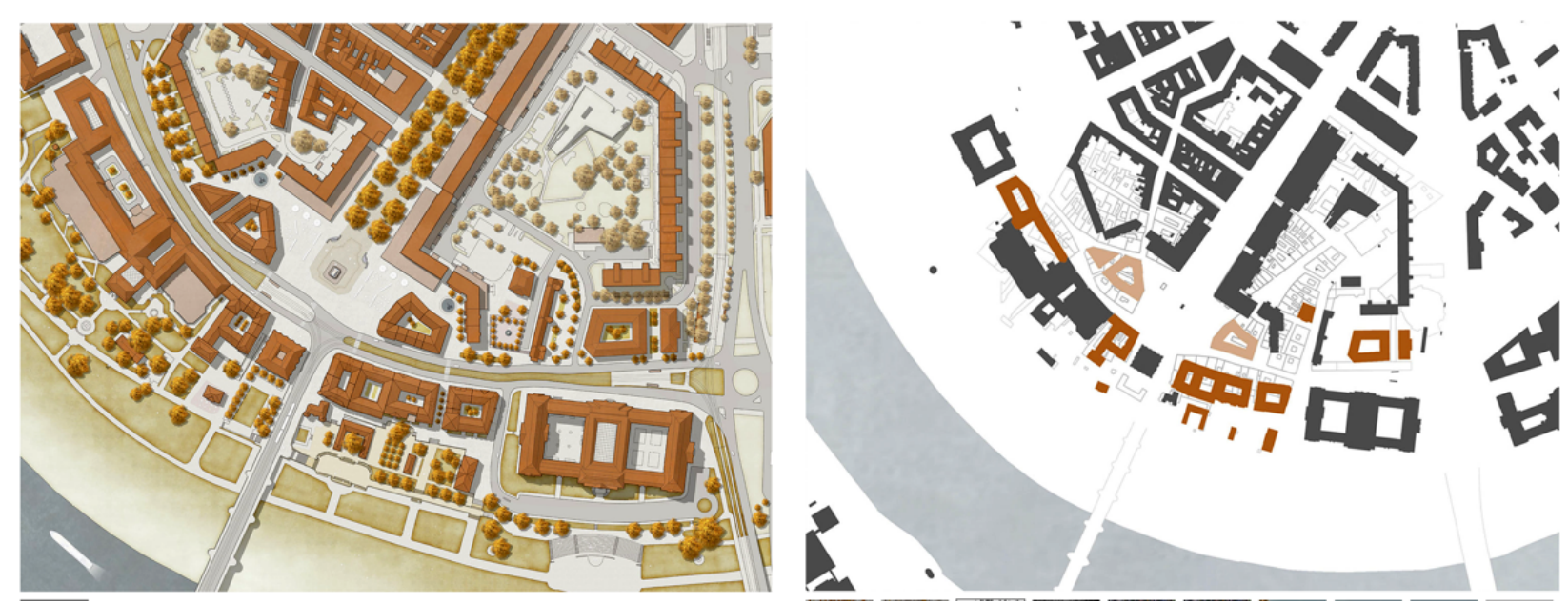

Figure 23. Königsufer and Neustädter Markt, Dresden, Bernd Albers. From left to right: masterplan; overlay on the historic fabric. Source: Albers (2018). 
in which present and past time layers complement each other productively. Thus, the connection between the Dresden Neustadt and the historic old city center can be experienced again. (Albers, 2018)

The theme of reconstruction and historical memory merges here with the intention of designing a new urban neighborhood, contemporary in contents and forms, with all the spatial and cultural qualities of the European city: High-density, multifunctionality, variety, orientation of the buildings towards the public space, address on the street/square, clear definition of the public space as the identity of the place. In contrast to Frankfurt, reconstruction is not the aim of the project. The relationship with history is, as always should be, a tool for a contemporary design (see Figure 24).

\section{Conclusions}

The Siedlung is based on a functional and rational model, which also includes, in a sense, a mechanistic declination of the way of life. The Stadtquartier presupposes, in addition to rationality and functionality, a cultural model based on the conventions of collective living. Both have to deal with the understanding that a big city is a cultural achievement with a long history, and the task of architecture and urban design is to implement its value and bring it into the future. If the experience of history teaches something, we must be wary of avant-garde manifestos and slogans. However, sometimes, in their immediacy, they indicate a path that is worth following.

If in the 1930s, the desired evolution was from the block to the bar, today it would seem that the famous May diagram should be mirrored, from the bar back to the urban block. The promised city of the post-war period that had to bring light and order, instead of the darkness and disorder of the ancient city, has not stood the test of time (see Figures 25 and 26).

The contemporary research on urban architecture is programmatically and decisively abandoning the Siedlung experience and returning to the search for a residential neighborhood with the traditional urban qualities of European cities. In this process, architects and urban designers can refer to a history spanning more than a century in the construction of urban architecture in big cities, with the aim of creating a contemporary, dense, plural, multifunctional and sustainable urban neighborhood, based on the close relationship between street, block, and building plot where architecture is the protagonist of the urban project.

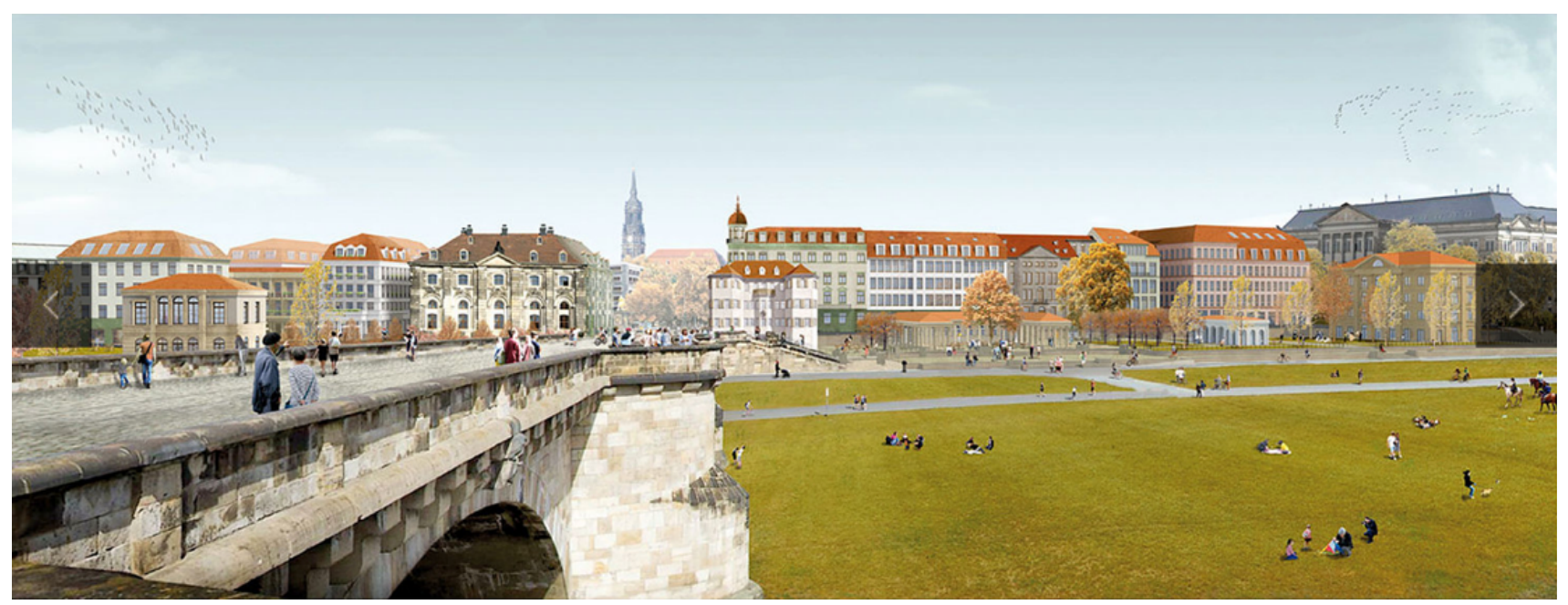

Figure 24. Königsufer and Neustädter Markt, Dresden, Bernd Albers. Perspective from the old city center. Source: Albers (2018).
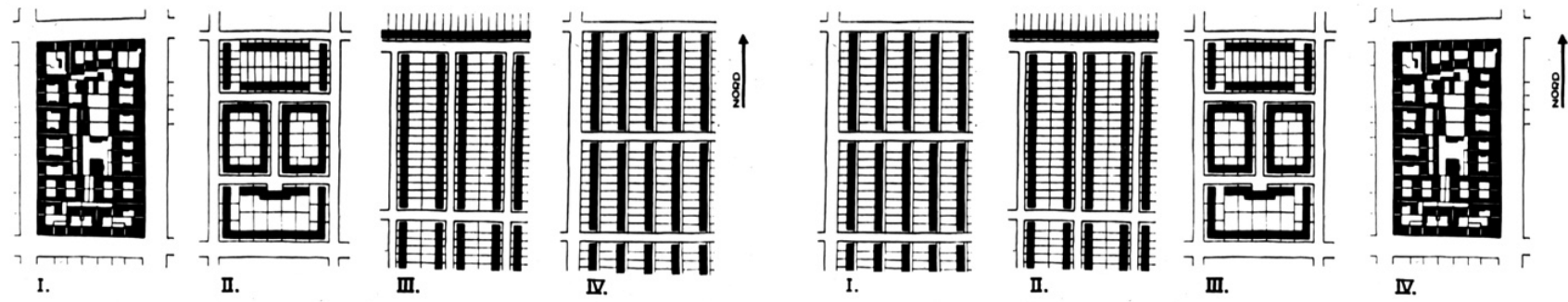

Figure 25. Entwicklung des Blocks in der Stadt [Development of the block in the city], 1930, original and mirrored diagram. Source: May (2011). 

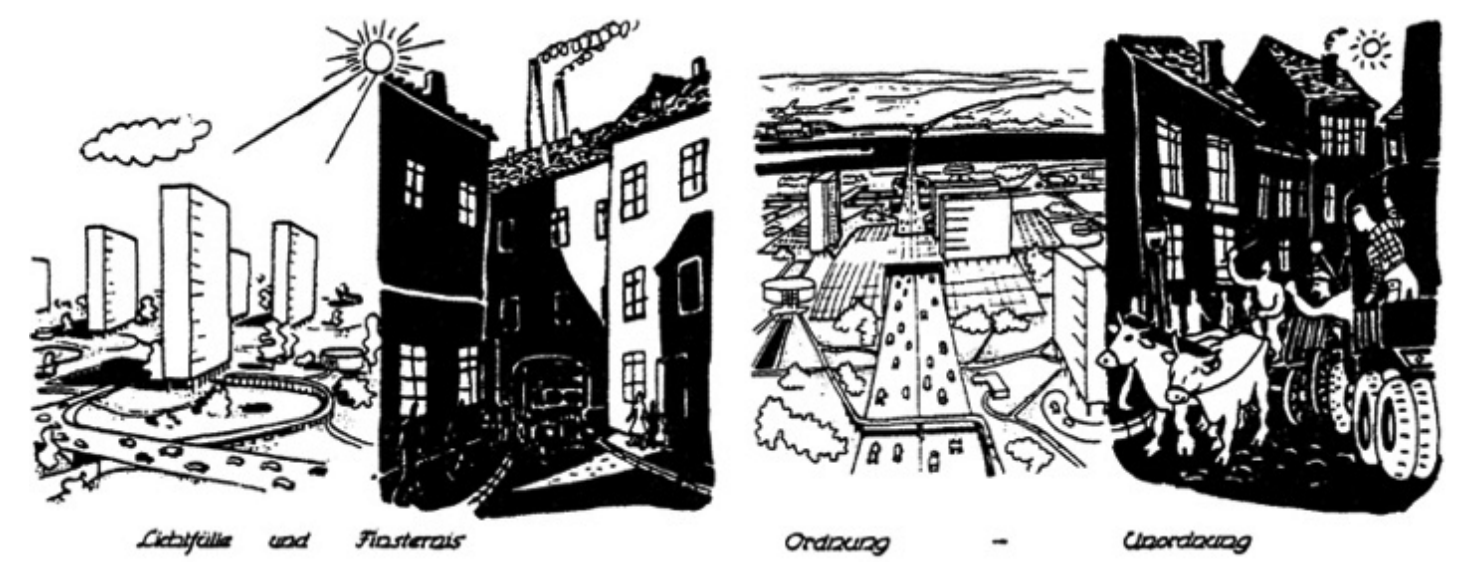

Figure 26. Reconstruction of Mainz, 1946-1948, Marcel Lods. Source: Cohen and Frank (2015).

\section{Acknowledgments}

I thank Manlio Michieletto and Alessandro Porotto for allowing me to consult their unpublished works and my colleagues Bernd Albers and Ludger Brands of the $\mathrm{FH}$-Potsdam for the valuable discussions on the contents.

\section{Conflict of Interests}

The author declares no conflict of interests.

\section{References}

Albers, B. (2018). Königsufer und Neustädter Markt Dresden [Königsufer and Neustädter Dresden market]. Retrieved from https://www.berndalbers.com/ koenigsufer-dresden

Arminius. (1874). Die Grossstädte in ihrer Wohnungsnoth und die Grundlagen einer durchgreifenden Abhilfe [The big cities in their housing emergency and the basics of a radical remedy]. Leipzig: Duncker \& Humblot.

Aymonino, C. (1971a). Origini e sviluppo della città moderna [Origins and development of the modern city]. Padova: Marsilio.

Aymonino, C. (1971b). L'abitazione razionale. Atti dei congressi CIAM 1929-1930 [Rational dwelling. Proceedings from CIAM 1929-1930]. Padova: Marsilio.

Baumeister, R. (1911). Städtebau [Urban design]. Karlsruhe: Polytechnischer Verein.

Bentlin, F. (2018). Understanding the Hobrecht Plan. Origin, composition, and implementation of urban design elements in the Berlin expansion plan from 1862. Planning Perspectives, 33(4), 633-655.

Bernet, C. (2004). The 'Hobrecht Plan' (1862) and Berlin's urban structure. Urban History, 31(3), 400-419.

Bernoulli, H. (1946). Die Stadt und ihr Boden [The city and its soil]. Erlenbach: Verlag für Architektur AG.

Bodenschatz, H. (1987). Platz frei für das neue Berlin! Geschichte der Stadterneuerung seit 1871 [Free up space for the new Berlin! History of urban renewal since 1871]. Berlin: Transit.
Brinkmann, A. E. (1920). Stadtbaukunst, geschichtliche Querschnitte und neuzeitliche Ziele [Urban architecture, historical cross sections and modern goals]. Berlin: Akademische Verlagsanstalt Athenaion.

Bruch, E. (1870). Berlins bauliche Zukunft und der Bebauungsplan [Berlin's structural future and the development plan]. Deutsche Bauzeitung, 4, 69-201.

Bullock, N., \& Read, J. (1985). The movement for housing reform in Germany and France 1840-1914. Cambridge: Cambridge University Press.

Cohen, J. L., \& Frank H. (Eds.). (2015). Mainz nach 1945: Die Stadtplanungen von Marcel Lods [Mainz after 1945: Marcel Lods' urban planning]. Basel: Birkhäuser.

Curdes, G. (1993). Stadtstruktur und Stadtgestaltung [Urban structure and urban design]. Stuttgart: Kohlhammer.

Deutscher Werkbund Berlin. (Ed.). (2016). WerkBundStadt Berlin Am Spreebord [WerkBundStadt Berlin on the Spree shore]. Berlin: Jovis.

Dolff-Bonkämper, G., Million, A., \& Pahl-Weber, E. (Ed.). (2018). Das Hobrechtsche Berlin, Wachstum, Wandel und Wert der Berliner Stadterweiterung [The Hobrechtsche Berlin, growth, change and value of the Berlin city expansion]. Berlin: Dom Publisher.

DomRömer. (2011). Das DomRömer Projekt [The DomRömer project]. DomRömer. Retrieved from https:// www.domroemer.de

Dreysse, D. W. (2001). May-Siedlungen. Architekturführer durch acht Siedlungen des neuen Frankfurt 1926-1930 [May-settlements. Architectural guide through eight settlements of the new Frankfurt 1926-1930]. Köln: Verlag der Buchhandlung Walter König.

Eberstadt, R. (1909). Handbuch des Wohnungswesens und der Wohnungsfrage [Manual of housing and housing question]. Jena: G. Fischer.

EU member states. (2007). Leipzig charter on sustainable European cities. European Commission. Retrieved from https://ec.europa.eu/regional_policy/archive/ themes/urban/leipzig_charter.pdf 
Geist, J. F., \& Kurvers K. (1980). Das Berliner Mietshaus 1740-1862 [The Berlin tenement 1740-1862]. Munich: Prestel.

Gessner, A. (1909). Das Berliner Mietshaus. Ein Beitrag zur Städtekultur der Gegenwart [The Berlin tenement. A contribution to the urban culture of the present]. Munich: Bruckmann.

Giedion, S. (1941). Space, time and architecture: The growth of a new tradition. Cambridge, MA: Harvard University Press.

Grassi, G. (Ed.). (1975). Das neue Frankfurt 1926-1931 [The new Franfurt 1926-1931]. Bari: Dedalo Libri.

Hegemann, W. (1930). Das steinerne Berlin. Geschichte der größten Mietkasernenstadt der Welt [The stone Berlin. History of the largest tenement city in the world]. Berlin: Kiepenheuer.

Kahlfeldt, P. (Ed.). (2016). Bauen und Wohnen. Die Geschichte der Werkbundsiedlungen [Building and living. The history of the Werkbundsiedlungen]. Berlin: Ernst Wasmuth.

Kleihues, J. P. (1973a). Berlin-Atlas zu Stadtbild und Stadtraum. Versuchsgebiet Kreuzberg [Berlin atlas on cityscape and urban space. Experimental area Kreuzberg]. Berlin: Der Senator für Bau- und Wohnungswesen.

Kleihues, J. P. (1973b). Berlin-Atlas zu Stadtbild und Stadtraum. Versuchsgebiet Charlottenburg [Berlin atlas on cityscape and urban space. Experimental area Charlottenburg]. Berlin: Der Senator für Bau- und Wohnungswesen.

Kleihues, J. P. (1978). Zeile oder Block? Neue versuche zum innenstädtischen Wohnen [Row or block? New attempts to inner-city living]. Neue Heimat, 25(11), 24-39.

Kleihues, J. P. (1979). Berliner Baublöcke. Grundriss einer Typologie [Berlin building blocks. Floor plan of a typology]. Werk Archithese, 66(31/32), 18-27.

Kleihues, J. P. (1981). Sieben Essentials zum Rahmenplan für die Neubaugebiete der Internationalen Bauausstellung Berlin [Seven essentials to the master plan for the new development areas of the International Building Exhibition Berlin]. Bauwelt, 72, 1589-1595.

Krier, R. (1975). Stadtraum in der Theorie und der Praxis [Urban space in theory and practice]. Stuttgart: Karl Krämer.

Lotus International (1978). L'isolato urbano/The urban block. Lotus International, 1978(19). Retrieved from http://www.editorialelotus.it/web/item.php?id=19

Lubowitzki, J. (1990). Der 'Hobrecht-Plan'. Probleme der Berliner Stadtentwicklung um die Mitte des 19. Jahrhunderts [The 'Hobrecht Plan'. Problems of the Berlin urban development around the middle of the 19th century]. In W. Ribbe (Ed.), BerlinForschungen [Berlin researches] (Vol. 5, pp. 11-130). Berlin: Colloquium.

Magnago Lampugnani, V., Albrecht, K., Bihlmaier, H., \& Zurfluh, L. (2017). Manuale zum Städtebau. Die Sys- tematisierung des Wissens von der Stadt 1870-1950 [Manuals for urban planning. The systematization of city's knowledge 1870-1950]. Berlin: DOM.

Magnago Lampugnani, V., Stühlinger, H. R., \& Tubbesing, M. (Ed.). (2018). Atlas zum Städtebau [Atlas for urban planning] (Vols. 1 and 2). Munich: Hirmer.

Malcovati, S. (2018). La WerkBundStadt è morta. Viva la WerkBundStadt [The WerkBundStadt is dead. Long live the WerkBundStadt]. AIÓN, 21, 119-125.

May, E. (2011). Das neue Frankfurt. Fünf Jahre Wohnungsbau in Frankfurt (1926-1930) [The new Frankfurt. Five years housing in Frankfurt (1926-1930)]. Frankfurt a. M.: Heinrich Editionen.

Michieletto, M. (2008). Comporre la Siedlung: il progetto della 'Niddatal' di Ernst May, Francoforte 1925-1930 [Composing the Siedlung: The "Niddatal" project by Ernst May, Frankfurt 1925-1930] (Unpublished Doctoral dissertation). Venice: Scuola di Dottorato, Università IUAV di Venezia.

Muratori, S. (1960). Studi per una operante storia urbana di Venezia [Studies for an operational urban history of Venice]. Roma: Istituto Poligrafico dello Stato.

Muratori, S. (1963). Studi per una operante storia urbana di Roma [Studies for an operational urban history of Rome]. Roma: Centro Studi di Storia Urbanistica.

Porotto, A. (2018), Logement de masse. Vienne et Francfort [Mass housing. Vienna and Frankfurt] (Unpublished Doctoral dissertation). Lausanne: Faculté de I'Environnement Naturel, Architecturale et Construit, Laboratoire de Construction et Conservation, École Polytechnique Fédérale.

Posener, J. (1979). Berlin auf dem Wege zu einer neuen Architektur [Berlin on the way to a new architecture]. Munich: Prestel.

Quiring, C., Voigt, W., Cachola Schmal, P., \& Herrel, E. (Eds.). (2011). Ernst May 1886-1970. Munich: Prestel.

Rodriguez-Lores, J., \& Fehl, G. (Eds.). (1988). Die Kleinwohnungsfrage Zu den Ursprüngen des sozialen Wohnungsbaus in Europa [The small housing question on the origins of social housing in Europe]. Hamburg: Christians.

Rogers, E. N. (1968). Editoriali di architettura [architecture editorials]. Torino: Einaudi.

Rossi, A. (1966). L'architettura della città [The architecture of the city]. Padova: Marsilio.

Rowe, C. (1984). IBA: Rowe reflects. The Architectural Review, 166(1051), 92-93.

Rowe, C., \& Koetter, F. (1978). Collage city. Cambridge, MA: MIT Press.

Scalvini, M. L., \& Sandri, M. G. (1984). L'immagine storiografica dell'architettura contemporanea da Platz a Giedion [The historiographical image of contemporary architecture from Platz to Giedion]. Roma: Officina Editori.

Scheffler, K. (1913). Die Architektur der Großstadt [The architecture of the big city]. Berlin: Cassirer.

Senator für Bau- und Wohnungswesen. (Ed.). (1978). Vor- 
lage über die Vorbereitung und Durchführung einer internationalen Bauausstellung in Berlin im Jahre 1984 [Presentation on the preparation and execution of an international building exhibition in Berlin in 1984]. Berlin: Senatsverwaltung für Bau- und Wohnungswesen.

Senatsverwaltung für Stadtentwicklung, Umweltschutz und Technologie. (Ed.). (1997a). Planwerk Innenstadt Berlin: Ergebnis, Prozess, Sektorale Planungen und Werkstätten [Blueprints for center Berlin: Result, process, sectoral planning and workshops]. Berlin: Kulturbuch.

Senatsverwaltung für Stadtentwicklung, Umweltschutz und Technologie. (Ed.). (1997b). Planwerk Innenstadt Berlin. Ein erster Entwurf [Planwerk downtown. A first draft]. Berlin: Kulturbuch.

Sonne, W. (2009). Dwelling in the metropolis: Reformed urban blocks 1890-1940 as a model for the sustainable compact city. Progress in Planning, 72(2), 53-150.

Sonne, W. (2014). Urbanität und Dichte im Städtebau des 20. Jahrhunderts [Urbanity and density in urban design of the 20th century]. Berlin: DOM.

Sonne, W. (2016). Städtebau versus Siedlungsbau. Der urbane Kontext zu den Werkbundsiedlungen im 20. Jahrhundert [Urban design versus settlement construction. The urban context in the Werkbundsiedlungen of the 20th century]. In P. Kahlfeldt (Ed.), Bauen und Wohnen. Die Geschichte der Werkbundsiedlungen [Building and living. The history of the Werkbundsiedlungen] (pp. 56-79). Berlin: E. Wasmuth Verlag.

Stimmann, H. (Ed.). (2002). Die gezeichnete Stadt. Die Physiognomie der Berliner Innenstadt in Schwarzund Parzellenplänen 1940-2010 [The drawn city. The physiognomy of the inner city of Berlin in black and plot plans 1940-2010]. Berlin: Nicolai.

Strohmeyer, K. (2000). James Hobrecht (1825-1902) und die Modernisierung der Stadt [James Hobrecht
(1825-1902) and the modernization of the city]. Berlin: Verlag für Berlin-Brandenburg.

Stübben, J. (1890). Der Städtebau. Handbuch der Architektur [The urban design. Manual of architecture] (Vol. 9). Darmstadt: Bergstrasser.

Sturm, P., \& Cachola Schmal, P. (Eds). (2018). Die immer Neue Altstadt. Bauen zwischen Dom und Römer seit 1900 [The ever new old town. Building between the cathedral and the Römer since 1900]. Berlin: Jovis.

Tubbesing, M. (2018). Der Wettbewerb Gross-Berlin 1910: Die Entstehung einer modernen Disziplin Städtebau [The Gross-Berlin competition 1910: The emergence of a modern urban planning discipline]. Berlin: Ernst Wasmuth.

Voigt, W., Deschermeier, D., \& Cachola Schmal, P. (Eds.). (2019). Neuer Mensch, neue Wohnung. Die Bauten des neuen Frankfurt 1925-1933 [New man, new dwelling. The buildings of the New Frankfurt 1925-1933]. Berlin: DOM.

Voigt, A., \& Geldner, P. (1905). Kleinhaus und Mietkaserne. Eine Untersuchung der Intensität der Bebauung vom wirtschaftlichen und hygienischen Standpunkt [Small house and tenements. An examination of the intensity of the development from the economic and hygienic point of view]. Berlin: Springer.

Wettbewerb Gross-Berlin. (1910). Wettbewerb GrossBerlin 1910: Die preisgekrönten Entwürfe mit Erläuterungsberichten [Competition Gross-Berlin 1910: The award-winning designs with explanatory reports]. Berlin: Wasmuth.

Wilde, A. (1989). Das Märkische Viertel [The Märkische Viertel]. Berlin: Nicolai.

Wolf, P. (1919). Städtebau. Das Formproblem der Stadt in Vergangenheit und Zukunft [Urban design. The form problem of the city in past and future]. Leipzig: Klinkhardt \& Biermann.

\section{About the Author}

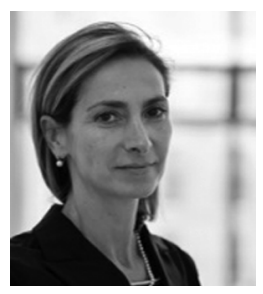

Silvia Malcovati, Architect, is Professor of Architecture and Urban Design at the Potsdam School of Architecture, Germany, since 2016. Born in Milan, she studied architecture in Milan and Barcelona and graduated in Milan with Giorgio Grassi in 1994. She has taught at the Politecnico di Torino (2002-2019), carried out research at ETH Zurich (1994-1995), achieved the title of PhD in Architectural Composition at the IUAV in Venice (1999), and worked as a post-doc at the Polytechnic of Milan (1999-2001). Her research has been focused on German architecture, particularly in Berlin, from K. F. Schinkel through $\mathrm{H}$. Tessenow and P. Behrens, up to contemporary Berlin and on the Italian architecture and theory of the post-war period. On these topics, she has organized lectures, conferences, and research projects and curated exhibitions and publication. 